\title{
"Like a Devoted Army": Medicine, Heroic Masculinity, and the Military Paradigm in Victorian Britain
}

\author{
Michael Brown
}

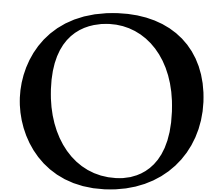

n 26 June 1847, the Lancet carried a notice announcing the death of the physician Jordan Roche Lynch at his house in Farringdon Street, London. Lynch, who was only thirty-eight, had died of a severe inflammation of the throat, the result of a typhus fever contracted in the course of his work with the sick poor of the West London Union. He left, the report stated, "a widow and young family to deplore his untimely death."

In the following weeks, Lynch's friends and fellow sanitary reformers arranged a subscription fund to provide for his wife and three children. ${ }^{2}$ Speaking to a meeting of the subscription committee, Edwin Chadwick asserted the claims of his family based on the fact that "the service in which Dr Lynch fell was a public service" and that "this service, against ravages greater than the ravages of war is, when closely pursued, attended with dangers really greater than those of military service." ${ }^{3} \mathrm{He}$ called those who had died treating the poor "fallen martyrs" who had "exhibited the most heroic virtue; for it was heroism of the highest kind to face certain danger without the stimulus of either excitement or glory." ${ }^{4}$ Chad-

Michael Brown is a Wellcome Trust Research Fellow at the Centre for the History of Science, Technology, and Medicine and Wellcome Unit, University of Manchester. Research for this article was carried out through the generous support of the Wellcome Trust. The author is grateful to Anna Clark and readers at the Journal of British Studies for their comments as well as to the wonderfully attentive Elizabeth Elbourne for her help in the latter stages. He is especially indebted to Lauren Goodlad, Ian Burney, and Catriona Kennedy for their help and guidance. He would also like to thank Stefanie Markovits for allowing him a preview of her excellent and important book.

1 "Medical News," Lancet 49, no. 1243 (26 June 1847), 688.

2 "The Late Dr Lynch," Lancet 50, no. 1247 (24 July 1847), 107-8.

${ }^{3}$ Health of Towns: Report of the Speeches of E. Chadwick, Esq., Dr Southwood Smith, Richard Taylor, Esq., James Anderton, Esq. and Others, at a Meeting Held at the London Coffee House on the 17th of August, 1847 to Promote a Subscription in Behalf of the Widow and Children of Dr J. R. Lynch (London, 1847), 5 .

4 “The Late Dr Lynch," Lancet 50, no. 1251 (21 August 1847), 209.

Journal of British Studies 49 (July 2010): 592-622

(C) 2010 by The North American Conference on British Studies.

All rights reserved. 0021-9371/2010/4903-0006\$10.00

\section{2}


wick's associate, Thomas Southwood Smith, made a similar point: "Of all the professions, the members of the medical profession are the shortest lived . . . because while the situation of the other learned professions is that of ease and safety, many of the members of the medical profession are engaged in a service as dangerous as that of the officers of the army in time of actual war."

The language used by Chadwick and Southwood Smith in recounting the noble life and tragic death of Dr. Lynch may be striking in its consistency, but it is far from unique for the period. Take, for example, a contemporaneous account of medical practice in Ireland in which the author claimed that "such a number of my pupils have been cut off by typhus fever as to make me feel very uneasy when any of them take a dispensary office in Ireland; I look upon it almost as going into battle." Finding that over 300 hospital and dispensary officers had died from typhus or other such diseases in the twenty-five years up to 1843 , the author suggested that the "mortality among [medical] men in the prime of life . . . is equal to the mortality in battle, and from wounds received in battle, during actual war." Such facts, he argued, would have a bearing not only on the appropriate remuneration of medical service but also "on the necessity of providing pensions for the wives and families of those who may fall before pestilence in the discharge of public duties," for "medical men who fall by fever are as entitled to pensions for their surviving relatives as soldiers who fall in battle."

Ever since the 1980s, feminist scholars and women's and gender historians have paid increasing attention to the ways in which medical knowledge about the body has shaped, informed, and intersected with wider understandings of gender identity, relation, and difference. ${ }^{7}$ Rather fewer have considered how formulations of gender informed the cultures of medicine itself. ${ }^{8}$ And yet the languages employed by men such as Chadwick and Southwood Smith in commemorating the life of their "fallen" colleague would suggest that medicine, as practice and self-representation, was framed by profoundly gendered discourses. In this article, I therefore want to consider the relationship between medicine and masculinity in the middle decades of the nineteenth century: to think about how the practice of medicine

\footnotetext{
${ }^{5}$ Health of Towns, 10.

6 "Mortality among Medical Men in Ireland," Lancet 50, no. 1250 (14 August 1847), 181-82.

${ }^{7}$ The literature on the relationship between medical knowledge and gender ideologies is too vast to list here, but a classic case in point is the work of Elaine Showalter and Ludmilla Jordanova. Elaine Showalter, The Female Malady: Women, Madness, and English Culture, 1830-1980 (New York, 1985); Ludmilla Jordanova, Sexual Visions: Images of Gender in Science and Medicine between the Eighteenth and Twentieth Centuries (London, 1989), and Nature Displayed: Gender, Science and Medicine, 1760-1820 (London, 1999).

${ }^{8}$ Exceptions to this general trend include Mary Poovey, “'Scenes of an Indelicate Character': The Medical 'Treatment' of Victorian Women," Representations, no. 14 (Spring 1986): 137-68; Christopher Lawrence, "Divine, Democratic and Heroic: The History and Historiography of Surgery," in Medical Theory, Surgical Practice: Studies in the History of Surgery, ed. Christopher Lawrence (London, 1992), 34-47; Ludmilla Jordanova, "Medical Men, 1780-1820," in Portraiture: Facing the Subject, ed. Joanna Woodall (Manchester, 1997), 101-15; Christopher Lawrence, "Medical Minds and Surgical Bodies: Corporeality and the Doctors," in Science Incarnate: Historical Embodiments of Natural Knowledge, ed. Christopher Lawrence and Steven Shapin (Chicago, 1998), 156-201; Ludmilla Jordanova, Defining Features: Scientific and Medical Portraits, 1660-2000 (London, 2000); Margaret Pelling, "Politics, Medicine, and Masculinity: Physicians and Office-Bearing in Early Modern England," in The Practice of Reform in Health, Medicine and Science, 1500-2000: Essays for Charles Webster, ed. Margaret Pelling and Scott Madlebrote (Aldershot, 2005), 81-106.
} 
was imagined and represented in gendered terms. In particular, I want to explore the ways in which certain members of the medical profession invoked and elaborated visions of masculinity framed by war, heroism, and self-sacrifice.

Historians have long recognized the prominence of the heroic trope within the Victorian cultural imagination. Thomas Carlyle's On Heroes, Hero-Worship and the Heroic in History (1841) laid the groundwork for a veritable obsession with heroism in Victorian Britain, expressed in visual, textual, and dramatic accounts of exemplary lives as well as in the inauguration and bestowal of awards such as the Victoria Cross (1856) and Albert Medal (1866). ${ }^{9}$ Heroism, and the essential disregard of self that underwrote it, was not the sole preserve of men in this period; women such as Grace Darling were immortalized within the popular consciousness. Neither was it limited to soldiers and sailors. Alongside the tradition of the martial champion sat the equally well-established tradition of religious martyrdom, rendered ever more culturally resonant in Victorian Britain by a revived evangelism and the expansion of foreign missionary activity. And yet while Grace Darling demonstrates that women could be represented as active and physically brave, and while male missionaries were as liable to martyrdom as their female counterparts, there nonetheless appears to have been a normative gendered dimension to these associations. As Judith Rowbotham has shown, articulations of religious martyrdom often emphasized a feminized and "passive endurance of unpleasantness or hardship," whereas heroism of the intrepid and courageous kind was generally associated with the masculine spheres of conflict and territorial expansion. ${ }^{10}$ Peter Stearns and Graham Dawson have claimed that it was this latter vision of the "soldier hero" that would, by the latter half of the nineteenth century, provide the exemplary model for middle-class imaginings and performances of manhood. ${ }^{11}$

At one level, then, medical men were operating within a broad cultural and discursive framework. Indeed, one of the purposes of this article is to demonstrate how medical practitioners drew on more general cultural resources and how particularly resonant visions of masculinity might be transposed, both as metaphor and ideology, across social groups and fields of practice. However, as Stefan Dudnik and Karen Hagermann have argued in their study of the gendering of politics and war, historical accounts of masculinity must not merely point to the presence of masculine discourses in any given situation but must analyze their "rhetorical and ideological efficacy in underwriting various arrangements of power" and understand the place of masculine rhetoric within "struggles over power, over claims to political and other forms of authority and legitimacy that were made in gendered

\footnotetext{
${ }^{9}$ Geoffrey Cubitt and Alan Warren, eds., Heroic Reputations and Exemplary Lives (Manchester, 1998); John Price, “'Heroism in Everyday Life': The Watts Memorial for Heroic Self-Sacrifice," History Workshop Journal 63, no. 1 (Spring 2007): 255-78.

${ }^{10}$ Judith Rowbotham, "'Soldiers of Christ'? Images of Female Missionaries in Late NineteenthCentury Britain: Issues of Heroism and Martyrdom," Gender and History 12, no. 1 (April 2000): 84.

${ }^{11}$ Peter N. Stearns, Be a Man! Males in Modern Society (New York, 1979); Graham Dawson, Soldier Heroes: British Adventure, Empire and the Imagining of Masculinities (London, 1994); Joseph Kestner, Masculinities in Victorian Painting (Aldershot, 1995), chap. 5; James Anthony Mangan, "Muscular, Militaristic and Manly: The British Middle-Class Hero as Moral Messenger," International Journal of the History of Sport 13, no. I (1996): 28-47; James Anthony Mangan and Callum McKenzie, “Duty unto Death?' The Sacrificial Warrior: English Middle-Class Masculinity and Militarism in the Age of the New Imperialism," International Journal of the History of Sport 25, no. 9 (2008): 1080-1105. See also George Lachmann Mosse, The Image of Man: The Creation of Modern Masculinity (Oxford, 1996).
} 
terms." ${ }^{12}$ My analysis shall therefore pay particular attention to the kinds of cultural work that such discourses were being made to perform.

This article is grouped into three key contextual clusters. The first of these focuses on the era of reform, particularly the sanitary crisis of the 1840s, and explores the cultural and political origins of a martial vision of medicine. In section I, I demonstrate how martial visions of medicine were shaped in accordance with a very particular sociopolitical agenda. Most closely associated with those at the lower end of the medical hierarchy, especially general practitioners occupying posts as poor law medical officers, and most frequently elaborated in the radical and reforming medical press, notably the Lancet, they serviced a specifically middleclass vision of professional medical identity. For poor law medical officers, an active role in the public space of urban squalor, as opposed to the private space of the consultation room or domestic abode, and a commitment to the health (physical and moral) of the working population, rather than to fee-paying patients, sustained a vision of disinterested public service that stood opposed to an aloof and selfinterested aristocratic culture, within both medicine and contemporary society more generally. During much of the period covered by this article, general practitioners were engaged in a campaign to reform the structures of medical governance, to depose the corporate medical elites and win authority themselves. ${ }^{13}$ The invocation of a militarized masculinity can therefore be understood as part of an internecine struggle for status. But its significance went far beyond this, to embrace the relations among expertise, authority, and political governance. Poor law medical officers were in the unique position in nineteenth-century medicine of being servants of the state. However, their relationship with local and central authority was a deeply vexed one, and many believed themselves to be underpaid and underappreciated. By shaping an active, intrepid, and self-sacrificing masculinity, and by comparing themselves to the army, they sought to draw attention to their own contribution to the national good. In so doing, they elaborated a middle-class vision of professional society defined by expertise and meritocratic reward. The "war" being fought was thus not simply one against dirt and disease; it was a struggle for the "Condition of England" in which bourgeois virtue arraigned itself against the equally malign forces of working-class fecklessness and aristocratic inefficiency.

It is clear, however, that the military itself occupied a complex and ambiguous position within nineteenth-century British thought. ${ }^{14}$ If the Napoleonic wars transformed Wellington's "scum of the earth" into noble defenders of British liberty, then the postwar period witnessed a significant decline in the army's popularity as it came to be associated with the suppression of political dissent, most notably with the involvement of the Manchester Yeomanry in the infamous Peterloo "massacre" of 1819 and the use of regular cavalry to disperse protestors and rioters in

\footnotetext{
${ }^{12}$ Stefan Dudnik, Karen Hagermann, and John Tosh, eds., Masculinities in Politics and War: Gendering Modern History (Manchester, 2004), 6.

${ }^{13}$ Ivan Waddington, The Medical Profession in the Industrial Revolution (Dublin, 1984); Irvine Loudon, Medical Care and the General Practitioner, 1750-1850 (Oxford, 1986).

${ }^{14}$ This is in contrast to the navy, which, for a variety of reasons, including its relative isolation from everyday civilian experience and its peacetime role in protecting British trade, remained a popular icon of British national identity, epitomized by the figure of the Jolly Jack Tar.
} 
Bristol in $1831 .{ }^{15}$ Even as late as the 1840 s, the army was still required to control civil disturbances, such as the Kennington Common Chartist rally in 1848. Against this, however, a number of historians have documented the growing popularity of the army throughout the early decades of the Victorian period. John MacKenzie argues for the importance of popular imperialism in sustaining this image, while Kenneth Hendrickson and Olive Anderson point to the Christianizing of the army ${ }^{16}$ Meanwhile, Scott Hughes Myerly has drawn attention to the role of ceremony and spectacle in constructing a "martial vision . . . throughout British society, promoting and advertising the adoption of 'military virtues' far beyond the military subculture." ${ }^{17}$ The 1850s are often seen as pivotal in this regard, with the Crimean war (1854-56), Indian "mutiny" (1857-59), French invasion scare (1859-60), and popular volunteer movement all combining to shape more positive representations of the army. And yet it is well marked that the Crimean war engendered a deep political and social crisis as the Army of the East's indifferent performance fueled public criticism of administrative inadequacies and incompetent aristocratic leadership. ${ }^{18}$

Section II considers how these ambivalent attitudes served to structure medical self-representation during and after the Crimean war. At one level, the Crimean crisis enhanced rather than devalued the imaginative associations between medical and military forms of heroic masculinity. With the manifest failures of the military leadership, public attention turned, in what Graham Dawson has termed "psychic reparation," to the bravery and fortitude of the rank and file. ${ }^{19}$ This was a "democratization" of heroism that, mediated through the figure of the army surgeon, was harnessed to a medical reformist agenda whose own valorization of grassroots sacrifice involved a similar critique of the "system" and of the corporate medical "aristocracy." At another level, however, these associations could prove untenable, as the increasing public valorization of the military throughout the $1850 \mathrm{~s}$ and 1860s far outstripped that of medicine. This section therefore examines how a failure to capitalize on the imaginative appeal of the army could exacerbate the tensions inherent in medical rhetoric, fueling the production of alternative dis-

\footnotetext{
${ }^{15}$ Kenneth Fox, Making Life Possible: A Study of Military Aid to the Civil Power in Regency England (Kingston upon Thames, 1982); Anthony Babbington, Military Intervention in Britain: From the Gordon Riots to the Gibraltar Incident (London, 1990), 71-97; Phillippa Morris, "Military Intervention in the Bristol Riots of 1831," Army Quarterly and Defence Journal 127, no. 2 (1997): 176-82; Scott Hughes Myerly, British Military Spectacle: From the Napoleonic Wars through the Crimea (Cambridge, MA, 1996), 120-38.

${ }^{16}$ John MacKenzie, "Introduction," in Popular Imperialism and the Military, 1850-1950, ed. John MacKenzie (Manchester, 1992), 1-24; Olive Anderson, "The Growth of Christian Militarism in MidVictorian Britain," English Historical Review 86, no. 338 (1971): 46-72; Kenneth Hendrickson, Making Saints: Religion and the Public Image of the British Army, 1809-1885 (London, 1998).

${ }^{17}$ Myerly, British Military Spectacle, 12, 139-73. See also Scott Hughes Myerly, "'The Eye Must Entrap the Mind': Army Spectacle and Paradigm in Nineteenth-Century Britain," Journal of Social History 26, no. 1 (Autumn 1992): 105-31.

${ }^{18}$ Olive Anderson, A Liberal State at War: English Politics and Economics during the Crimean War (London, 1967), and "The Administrative Reform Association, 1855-1857," in Pressure from Without in Victorian England, ed. Patricia Hollis (London, 1974), 262-88; John Peck, War, the Army and Victorian Literature (Basingstoke, 1998); Stefanie Markovits, The Crimean War in the British Imagination (Cambridge, 2009).

${ }^{19}$ Dawson, Soldier Heroes, 27-52.
} 
courses in which the essential humanity of the medical endeavor was counterposed to the destructive tendencies of war.

Section III adopts a more thematically speculative approach. Telescoping from the 1860s through to the end of Victoria's reign, it considers how these tensions in medical rhetoric played out against the background of domestic and international politics. In particular, it contemplates the impact of the foundation of the Red Cross and the rise of a culture of international medical humanitarianism on an engagement with the military paradigm, before postulating how this engagement was simultaneously enhanced and transformed by the advent of new imperialism, particularly the South African War of 1899-1902.

As we shall see, this is not a simple story, and perhaps the most important purpose of this essay is to highlight the essential ambivalence of medicine's gendered identity. As Mary Poovey's work on Florence Nightingale has suggested, mid-nineteenth-century forms of female medical labor developed in dialectic tension with a nascent professional ideal, struggling to locate themselves between masculine public service and domestic "housewifely" virtue. ${ }^{20}$ Thus, while medical invocations of military masculinity were rarely aimed at women directly, they might still be seen as a counterpoint to Poovey's discussion of Nightingale, an attempt to construct medicine as an exclusively masculine domain to divest it of its domestic associations and to harvest forms of symbolic capital that were significantly less accessible to women.

And yet if Nightingale's gender identity was problematic, then that of male general practitioners was no less so. For all of their investment in a militarized masculinity, medicine remained stubbornly intertwined with the domestic, feminine, not to say maternal, values of nurture and care. Even their more explicit invocations of militarism were therefore marked by ambiguity and contradiction. After all, whereas soldiers were expected to kill, medical practitioners were not (at least not intentionally). They may have represented disease and social deprivation as an enemy to be fought, but their essential mission remained humanitarian rather than destructive. This produced an inherent tension within medical rhetoric, with practitioners frequently oscillating between religious and warlike imagery and between feminized and masculinized visions of medicine. To a degree, the parallel development of "Christian militarism" and "muscular Christianity" served to ease these tensions, elaborating a vision of war that was compatible with moral and spiritual rectitude and that was epitomized by the figure of Henry Havelock, the heroic soldier saint.$^{21}$ Nevertheless, they were never satisfactorily resolved, at least not until later in the century-perhaps not even then.

\section{MASCULINITY AND MILITARISM IN THE SANITARY ERA}

The genealogical origins of war as an imaginative and rhetorical trope in British medicine can be located in the masculine cultures of early nineteenth-century reform. During the later eighteenth century, medical practice was, for the most

\footnotetext{
${ }^{20}$ Mary Poovey, Uneven Developments: The Ideological Work of Gender in Mid-Victorian England (Chicago, 1989), chap. 6.

${ }^{21}$ Anderson, "Christian Militarism"; Hendrickson, Making Saints.
} 
part, gendered along the lines of polite and civil gentility. ${ }^{22}$ However, as the number of practitioners increased in the decades after the end of the Napoleonic wars and as pressure grew from among the lower ranks for the structural and political reform of the discipline, medical discourse took a distinctly masculinist turn. Through the languages of "brotherhood" and upright, "manly opposition," medical reformers redefined themselves as a discrete, professional body, distinct from the penumbra of health care, and asserted their rights as independent men, both against the corporate aristocratic elite and within the social field as a whole. ${ }^{23}$ Perhaps the clearest exponent of such language was the radical general practitioner and editor of the Lancet, Thomas Wakley, whose frequently vicious and libelous attacks on "Old Corruption" in medicine mirrored the language of his political associate William Cobbett.

Although masculine rhetoric was prevalent within medical reformist discourse as a whole, it was in the field of sanitary medicine that the particular tropes of a heroic and militarized masculinity were elaborated and deployed. The first collective medical engagement with the health and social conditions of the poor took place during the cholera epidemic of 1831-32. Traditionally, medical practitioners had felt little compulsion to take an active role in mitigating epidemic disease. ${ }^{24}$ During the cholera epidemic, however, doctors and surgeons sat on local boards of health and often found themselves treating the very poorest members of society in temporary cholera hospitals or in the homes of the sick, often without charge. ${ }^{25}$ The medical response to cholera was undermined by divisions concerning its epidemiology and by popular hostility engendered by the Anatomy Act (1832), which allowed medical practitioners access to the unclaimed bodies of the poor for the purposes of dissection and which fueled popular distrust of their activities. Nevertheless, in more "elevated" social circles at least, it served to enhance the moral authority of medicine. ${ }^{26}$ At a meeting of the local board of health in August 1832, for example, the Dean of York praised the "zeal and activity with which they

${ }^{22}$ Mary Fissell, "Innocent and Honourable Bribes: Medical Manners in Eighteenth-Century Britain," in The Codification of Medical Morality: Historical and Philosophical Studies of the Formalization of Western Medical Morality in the Eighteenth and Nineteenth Centuries, vol. 1, Medical Ethics and Etiquette in the Eighteenth Century, ed. Robert Baker, Dorothy Porter, and Roy Porter (London, 1993), 15-45; John V. Pickstone, "Thomas Percival and the Production of Medical Ethics," in Baker, Porter, and Porter, eds., 161-78; Lisbeth Haakonssen, Manners and Morals in the Enlightenment: John Gregory, Thomas Percival and Benjamin Rush (Amsterdam, 1997); Michael Brown, "From the Doctors' Club to the Medical Society: Medicine, Gentility and Social Space in York, 1780-1840," in EighteenthCentury York: Culture, Space and Society, ed. M. Hallett and J. Rendall (York, 2003), 59-69.

${ }^{23}$ Matthew McCormack, The Independent Man: Citizenship and Gender Politics in Georgian England (Manchester, 2005); Michael Brown, "Medicine, Reform and the 'End' of Charity in Early NineteenthCentury England," English Historical Review 124, no. 511 (December 2009): 1353-88.

${ }^{24}$ Patrick Wallis, "Plagues, Morality and the Place of Medicine in Early Modern England," English Historical Review 121, no. 490 (February 2006): 1-24.

${ }^{25}$ Robert John Morris, Cholera 1832: The Social Response to an Epidemic (London, 1976); Michael Durey, The Return of the Plague: British Society and the Cholera, 1831-2 (Dublin, 1979).

${ }^{26}$ Michael Durey, "Medical Elites, the General Practitioner and Patient Power in Britain during the Cholera Epidemic of 1831-2," in Metropolis and Province: Science in British Culture, 1780-1850, ed. Ian Inkster and Jack Morrell (London, 1983), 274; Durey, Return of the Plague, 105-20, 162-84; Sean Burrell and Geoffrey V. Gill, "The Liverpool Cholera Epidemic of 1832 and Anatomical Dissection-Medical Mistrust and Civil Unrest," Journal of the History of Medicine and Allied Sciences 60, no. 4 (October 2005): 479-98. 
[medical men] had come forward to stay the progress of the disease; that they had exposed themselves and their families to the most imminent danger of contagion; that they had passed sleepless nights, in affording assistance to their fellow creatures; and that they had stood up between the dead and the living, and stopped the plague. ${ }^{27}$

Yet if the medical response to the cholera epidemic of 1831-32 had been a broadly collective one, an expedient response to a national crisis, then the routine business of sanitary medicine would fall to a more specific group of practitioners. In 1834, the Poor Law Amendment Act created the post of District Medical Officer to minister to the health of the lower orders. At one level, this was a hugely significant development, for in the words of Chris Lawrence, the post of District Medical Officer constituted "the principal means by which medicine was harnessed into the running of nineteenth-century society." ${ }^{28}$ At another level, however, the professional status and identity of the District Medical Officer were deeply vexed. The preserve of the struggling general practitioner, the position was poorly paid, tendered out to the lowest bidder. The authority and autonomy of the District Medical Officer were likewise limited, undercut by the contempt with which he was so often treated by both lay guardians and the medical hierarchy alike. ${ }^{29}$ It is this liminality of identity that provides the key to understanding the rhetorical elaboration of a militarized medical masculinity. As Priti Joshi's study demonstrates, Edwin Chadwick's intellectual dominion over the poor can be read as part of an attempt to construct a social and gender identity that, in the absence of a stable career, derived authority from merit and expertise rather than from the aristocratic values of kinship and patronage to which he had little access. ${ }^{30}$ The same can be said of those appointed to the positions he created. Undervalued by the state and disdained by their socially superior colleagues, poor law surgeons shaped a solidly middle-class masculinity that, in emphasizing the values of disinterested public service and heroic self-sacrifice, worked against their marginalization, even feminization, as economically dependent supplicants. As with Chadwick, this identity was directed upward, against the self-interested medical elite and aristocratic government that neglected them, as well as downward, against the poor, whose idleness and amoral complicity in their own pestilential environment they sought so vigorously to reform.

Although they bubbled away under the surface of medical discourse throughout the later 1830s, these issues really came to a head during the social and sanitary crises of the "hungry" 1840s. An increased popular interest in the social conditions of the poor, exemplified by the extensive circulation and widespread impact of Chadwick's Report on the Sanitary Condition of the Labouring Population of Great

27 "Board of Health," Yorkshire Gazette, 11 August 1832.

${ }^{28}$ Christopher Lawrence, Medicine in the Making of Modern Britain, 1700-1920 (London, 1994), 43.

${ }^{29}$ Ruth G. Hodgkinson, The Origins of the National Health Service: The Medical Services of the New Poor Law, 1834-1871 (London, 1967), 66-146; Michael W. Flinn, "Medical Services under the New Poor Law," in The New Poor Law in the Nineteenth Century, ed. Derek Fraser (London, 1976), 45-66; Anne Digby, Making a Medical Living: Doctors and Patients in the English Market for Medicine, 1720-1911 (Cambridge, 1994), 50.

${ }^{30}$ Priti Joshi, "Edwin Chadwick's Self-Fashioning: Professionalism, Masculinity and the Victorian Poor," Victorian Literature and Culture 32, no. 2 (September 2004): 353-70. 
Britain (1842), ${ }^{31}$ highlighted the role of the poor law surgeon as the figure in respectable society most consistently exposed to the blighted lives of the "lower orders." ${ }^{32}$ So too did the epidemiological situation. Typhus remained virtually endemic in many urban areas of Britain, while in Ireland it combined with the debilitating consequences of the famine to cut swathes through the population. ${ }^{33}$ To make matters worse, the dreaded scourge of cholera returned to British shores once again in the autumn of 1848 , encouraging a hitherto ambivalent Parliament to pass the Public Health Act. ${ }^{34}$

Rhetoric aside, it is clear that poor law surgeons did suffer from relatively high levels of mortality in this period. Medical journals carried a consistent stream of obituaries and notices recording the deaths of practitioners who had, it was believed, contracted disease as a consequence of their work with the sick poor. The situation in Ireland was particularly severe. In September 1847, the Lancet announced that "not a week elapses but some Irish surgeon falls victim to the pestilence which has now so long prevailed . . . and yet the individuals who are struck down in their endeavour to aid their afflicted neighbours fall disregarded by the legislature." ${ }^{35}$ Matters in Britain were not much better. In one week alone in January 1848, the Journal of Public Health recorded the deaths from typhus of ten practitioners "in the Discharge of Public Duty." 36

It was in this period, then, that the imagery and rhetoric of heroic self-sacrifice was first most widely articulated, not only with the death of Dr. Lynch but in the obituaries of men such as Robert Storrs, surgeon to the Doncaster Union, which recorded how he had "died on the field of duty," or that of Joseph Williams of Stokes Croft in Bristol, which claimed that "his life was glorious and his death

\footnotetext{
${ }^{31}$ Flinn goes so far as to suggest that as many as 20,000 copies of the Report were sold. Michael W. Flinn, "Introduction," in Report on the Sanitary Condition of the Labouring Population of Great Britain by Edwin Chadwick (Edinburgh, 1965), 55. While acknowledging that sales were good "for a blue book," Hamlin puts the figure much lower, at around 500 sold and 500 distributed to relevant officials. Christopher Hamlin, Public Health and Social Justice in the Age of Chadwick: Britain, 1800-1854 (Cambridge, 1998), 155 n. 97.

${ }^{32}$ So much so, in fact, that the comparative ignorance of the "better sort" with regard to the poor was to become a rhetorical staple for sanitary reformers such as Thomas Southwood Smith. First Report of the Commissioners for Inquiring into to the State of Large Towns and Populous Districts, 2 vols. (London, 1844), 1:32; “The Late Dr Lynch,” Lancet 50, no. 1251 (21 August 1847), 210.

${ }^{33}$ John V. Pickstone, "Dearth, Dirt and Fever Epidemics: Rewriting the History of British 'Public Health,' 1780-1850," in Epidemics and Ideas: Essays on the Historical Perception of Pestilence, ed. Terrence Ranger and Paul Slack (Cambridge, 1992), 125-48; Christopher Hamlin, "Can You Starve to Death in England in 1839? The Chadwick-Farr Controversy and the Loss of the Social in Public Health," American Journal of Public Health 85, no. 6 (June 1995): 856-66, and "Edwin Chadwick, 'Mutton Medicine' and the Fever Question," Bulletin of the History of Medicine 70, no. 2 (Summer 1996): 233-65; Leslie A. Clarkson and E. Margaret Crawford, Feast and Famine: A History of Food and Nutrition in Ireland, 1500-1920 (Oxford, 2001), 134-63.

${ }^{34}$ Flinn, "Introduction," 70-71; Hamlin, Public Health, 245-74.

35 "Medical News: Obituary-Irish Surgeons," Lancet 50, no. 1253 (4 September 1847), 267. See also "Medical News: Mortality of Medical Men," Lancet 51, no. 1271 (8 January 1848), 56; and Gavin Milroy, "Letter to the Editor: Frightful Morality of Medical Practitioners in Ireland," Lancet 51, no. 1278 (26 February 1848), 241.

${ }^{36}$ Cited in "Mortality of Medical Men," Lancet 51, no. 1271 (8 January 1848), 55. See also "Medical News: Obituary," Lancet 53, no. 1327 (3 February 1849), 136.
} 
triumphant. ${ }^{37}$ In medical lectures, such language was similarly prominent. Speaking to the London Hospital Medical School in October 1847, George Critchett praised the activities of medical men in the field of sanitary reform, claiming that "with all the heroism of the champion, and, alas! too often with all the faithful devotion of the martyr, have some of the brightest ornaments of our profession pursued their untiring labours amid the ravages of contagious fever. . . . They seem to realize the glory of the prophet of old, when he stood between the living and the dead, and stayed the progress of the destroying angel as he swept through the armies of Israel." ${ }^{38}$

Although these discourses emerged within the field of public health and were intimately linked to a specific set of political grievances, their imaginative appeal was such that they embraced situations and individuals unconnected to the immediate sanitary crisis. In December 1845, for example, the Lancet ran a story on "the heroic Sidney Bernard," an English surgeon who died after having voluntarily boarded a plague-stricken ship in Madeira. ${ }^{39}$ Similarly, in recording the 1854 death of a Dr. Cunningham, who was swept away trying to save the passengers of the shipwrecked Tayleur, the Lancet announced that "it is impossible not to be deeply moved by heroism like this, and it is with a deep sense of admiration and sympathy that we express our regret at the fate of so brave and worthy a professional brother." ${ }^{\prime 40}$ Indeed, so pervasive was the language of medical heroism that even more routine accidents were subject to reinterpretation. When the University College London medical student John Phillips Potter died from an infection contracted during dissection, the professors and students of the university decided to erect a statue to him. ${ }^{41}$ The Lancet declared that "the victims of dissection ought to hold a distinguished place among the martyrs to science and knowledge: Braving the dangers of this death is one of the silent heroisms of our profession, which should make the medical man feel the pride of courage and endurance; and we are the more reminded of these things at the present time, when numbers of professional men, in this country and in Ireland, are falling victims to their attendance on the pestilential fever produced by famine." ${ }^{\$ 2}$

As is apparent from the Lancet's elegy to Potter and from Critchett's speech to his students, contemporary medical discourse often combined active, intrepid, and warlike languages of courage and bravery with more passive languages of selfsacrifice, victimhood, and martyrdom. These more feminized and quasi-religious tropes were tinged by the domestic dimensions of professional identity and by the duties of pastoral care that linked medicine to the church. Indeed, as a model for medical professional identity, the church seemed the most obvious choice, just as

\footnotetext{
37 "Medical News: Obituary," Lancet 50, no. 1258 (9 October 1847), 396; "Medical News: Obituary," Lancet 54, no. 1359 (15 September 1849), 306.

${ }^{38}$ George Critchett, "Introductory Lecture Delivered at the London Hospital Medical School at the Commencement of Session 1847-8," Lancet 50, no. 1260 (23 October 1847), 429.

39 "News of the Week: The Bernard Testimonial," Lancet 46, no. 1164 (20 December 1845), 687.

40 "Medical News: Heroism of a Surgeon," Lancet 63, no. 1588 (4 February 1854), 147. The RMS Tayleur was a White Star Line clipper that ran aground on Lambay Island (off Dublin Bay) during its maiden voyage to Australia, with the loss of 270 lives. It remained one of the most notorious shipwrecks of the nineteenth century. For more on the roles, responsibilities, and actions of doctors at sea, see Robin Haines, Doctors at Sea: Emigrant Voyages to Colonial Australia (Basingstoke, 2005).

41 “Obituary: John Phillips Potter, FRCS," Lancet 49, no. 1239 (29 May 1847), 576-77.

42 "Statue to Mr. J. P. Potter in University College," Lancet 49, no. 1241 (12 June 1847), 625.
} 
martyrdom seemed the most obvious template for medical heroism. There was, after all, very little that poor law surgeons such as Lynch, or medical students such as Potter, could have done to avoid their fates. Death from disease was unfortunate and accidental, rather than a willful act of reckless daring. By invoking the image of martyrdom, their deaths could be sublimated into ennobling exemplars of a pervasive, if "silent," medical heroism. The dead man became a source of collective "pride" in duty, as opposed to an object of mere pity or sympathy. In the case of Potter in particular, victimhood and martyrdom also had other rhetorical and political uses. In the wake of the deeply controversial Anatomy Act, the language of martyrdom served to counter a popular caricature of the medical man as a heartless dissector of the bodies of the poor.

What is remarkable, then, is not the prevalence of religious imagery and languages in contemporary discourse but the fact that it was the military paradigm, rather than the ecclesiastical, that came to dominate reformist cultures of medical self-representation. In anticipation of a second cholera epidemic, for example, Wakley asked: "When [cholera] visited this country before, upon whom did its burden of anxiety, expense, and danger, principally fall? Upon medical men. And now, a second time, this destroyer is coming westward over the globe . . . and a second time the medical profession, to the number of nearly thirty thousand, like a devoted army, will have to stand, in the danger of contagion, between the people and this fatal pestilence."43

Given what I have said about the ambiguous position of the army in British society in the 1840s, why would Wakley, a political radical and Chartist sympathizer, choose to compare the medical profession to the army? Of course Wakley did not invoke an image of the British army, per se, but rather a metaphoric abstract, suggesting that one might well employ military analogies without expressing support for the status quo. Nevertheless, the use of such language might also suggest that Myerly's "martial vision" was well established by the late 1840s and that his early nineteenth-century chronology is not quite as inappropriate as his critics have alleged. ${ }^{44}$ After all, in this period the army was both less visible as a potentially repressive domestic force (there were only nineteen regular battalions stationed on British soil in 1841) and also at its most militarily active, participating (along with the troops of the East India Company) in a range of foreign and imperial conflicts, including the Afghan (1838-42), opium (1839-42), and Sikh wars (1845-46, 1848-49). ${ }^{45}$ This combination of heightened popular awareness with relative imaginative distance (except, perhaps, as mediated through the spectacular form of parades and displays) may well have helped to shape more popular visions of the army, comparable to those of the Royal Navy.

More important, for my purposes at least, the military paradigm performed a set of political and rhetorical functions within medical discourse that the religious trope simply could not. First, by emphasizing courage and valor at the expense of domestic or pastoral care, it shaped an active, public, and overtly masculine identity that not only rendered medicine distinct from the church but, crucially,

\footnotetext{
43 "Prospect of Sanitary Laws and Regulations," Lancet 48, no. 1193 (11 July 1846), 53; my emphasis.

${ }^{44}$ See, e.g., Ian F. W. Beckett, review of British Military Spectacle, by Scott Hughes Myerly, American Historical Review 103, no. 3 (June 1998): 884-85.

${ }^{45}$ Ibid., 884.
} 
was comparatively less accessible to women involved in the sphere of health care, be they nurses, midwives, or even mothers, sisters, or daughters attendant on the sick. Militarism was thus a potent tool of identity formation, constructing medicine as a unique, bounded, and masculine activity.

The second function of the developing military paradigm was the alignment of medical identity with the image of an army that was a truly national institution, representing and defending the interests of the nation as a whole. In contrast, the religious sphere remained divided along sectarian lines between Anglicans, Catholics, and dissenters, as well as between the Episcopal Church of England and the Presbyterian Church of Scotland. ${ }^{46}$ By aligning themselves with the army, medical practitioners (in particular poor law surgeons) were therefore able to claim that they too represented the state and that, like soldiers, they were required to lay down their lives in the national interest as defenders of the "people."

While cultivating the symbolic capital associated with the army, however, such analogies also served to highlight the discrepancy between medical and military service. As I have suggested, reformist visions of meritocratic reward were just that, visions. They presented things as they should be, not as they were. In the majority of cases in which medical writers employed the trope of militarism, the public and governmental estimation of military sacrifice was therefore contrasted with the absence of an equivalent appreciation in matters medical. "If they survive the hazard of war," the Lancet claimed of military officers in 1853, "applause, wealth [and] high places are their reward. If they perish, national honours are decreed to their memories, history records their devotion and their ends." By contrast, poor law surgeons and sanitary doctors, who engaged in "another kind of public duty, more perilous than war . . . sacrific[ing] their health and all social comfort," received no such plaudits. ${ }^{47}$ As with many reformist causes, France provided an enviable contrast to the situation in Britain. ${ }^{48}$ Throughout the later 1840s, the Lancet regularly reported on the bestowal of medals and other such honors on French medical men. Commenting on the award of the Legion d'Honneur to the staff of the Parisian hospitals for their service in the cholera epidemic, it lamented that "honorary distinctions are so much less frequently awarded in this country. . . They are great incentives to zeal and emulation. . . . Cheap to the giver, they are highly valued by the recipient." ${ }^{49}$

Medals and awards, although desirable, were not the most important issue, for what most animated medical reformers was the financial security of familial dependants. With a marked increase in medical mortality, it is perhaps little surprise that the 1840s saw the proliferation of medical benevolent societies and subscrip-

\footnotetext{
${ }^{46}$ Laurence W. B. Brockliss, "The Professions and National Identity," in A Union of Multiple Identities: The British Isles, c. 1750-c. 1850, ed. Laurence W. B. Brockliss and David Eastwood (Manchester, 1997), 9-28.

47 "The Public and the Profession," Lancet 62, no. 1576 (12 November 1853), 464-65.

${ }^{48}$ See, e.g., Adrian Desmond, The Politics of Evolution: Morphology, Medicine and Reform in Radical London (Chicago, 1989); John Harley Warner, "The Idea of Science in English Medicine: The 'Decline' of Science and the Rhetoric of Reform, 1815-45," in British Medicine in an Age of Reform, ed. Roger French and Andrew Wear (London, 1991), 135-63; Ian Burney, "Medicine in the Age of Reform," in Rethinking the Age of Reform: Britain, 1780-1850, ed. Arthur Burns and Joanna Innes (Cambridge, 2003), 163-81.

49 "Medical Honours," Lancet 54, no. 1358 (8 September 1849), 273.
} 
tion funds to support the families of deceased medical men. However, those who presented medicine as a public office did not regard such matters as the responsibility of the profession. "The widows and orphans of the naval and military services are provided for by the state," the Lancet observed, while those of "medical practitioners . . . [who] fall in the actual service of the public . . . have but the most scanty, the most precarious, and the most partial security against absolute want and misery. . . . If a man fall in the service of the State, it is the duty of the State to adopt and protect his widow and orphans." ${ }^{" 50}$ Although certainly a genuine concern, the consistent emphasis placed on the fate of familial dependents by medical commentators also possessed great rhetorical power, for the image of the grieving widow and absent paterfamilias struck at the heart of an early Victorian conception of masculinity wherein the affective claims of the domestic sphere underwrote the nobility of public duty. ${ }^{51}$

Needless to say, these visions of medicine, and of the kind of state to which it might be allied, were by no means universally shared. Most medical practitioners, including almost all reformers and even some of those more elite practitioners who earned their livings exclusively from private practice, supported a degree of state recognition, be that licensing and regulation or merely a greater appreciation of medicine's contribution to the social good. Few, however, even within the reformist camp, would have wanted medicine to become a tool of state governance tout court. And yet for many District Medical Officers, who were already in some sense employed by the state, the idea of a comprehensive, regulated, and centralized system of state medicine was highly appealing in that the bureaucratic structures of public service provided them with their likeliest source of political and social authority, both as doctors and as men. ${ }^{52}$ The Revered J. B. Owen spoke for many such individuals when, at a meeting of the Wolverhampton Health of Towns Association in 1848, he argued that "the medicine-man must henceforth be an officer of Government, endowed with rank, and commissioned with power . . . and if we decorate with medals, and recompense with pensions, our naval and military and other servants of the State . . . let not the men who daily encounter perils not a whit less fatal than those which battle brings into the field or fleet be any longer excluded from the well-earned gratitude of the nation." ${ }^{53}$

Owen's speech hints at the degree to which images of heroic masculinity developed within the medical press reached out into the wider public realm. In 1847, The Times carried an article on the "heroism of the clergy and medical men" in the face of typhus, while in the same year an anonymous contributor to the Lancet

\footnotetext{
50 "The Public and the Profession," Lancet 62, no. 1576 (12 November 1853), 464-65.

${ }^{51}$ John Tosh, A Man's Place: Masculinity and the Middle-Class Home in Victorian England (New Haven, CT, 1999), 123-42; Trev Lynn Broughton and Helen Rogers, eds., Gender and Fatherhood in the Nineteenth Century (Basingstoke, 2007).

${ }^{52}$ For a comparative perspective on masculinity, authority, and the bureaucratic state, see Francis Dodsworth, "Masculinity as Governance: Police, Public Service and the Embodiment of Authority, c. 1700-1850," in Public Men: Masculinity and Politics in Modern Britain, ed. Matthew McCormack (Basingstoke, 2007), 33-53.

53 “Medical News: Wolverhampton-Health of Towns," Lancet 51, no. 1278 (26 February 1848),
} 
claimed that the deaths of so many District Medical Officers had extended "sympathy . . . beyond the pale of their own profession." 54

Even more suggestive, perhaps, is the reception of medical heroism within the contemporary literary imagination, particularly in the work of Charles Dickens. Dickens entertained a profound interest in sanitary reform and was friends with a number of medical practitioners, including Thomas Southwood Smith. ${ }^{55}$ His receptivity to the claims of medical rhetoric is best exemplified by the character of Allan Woodcourt in Bleak House, published serially between March 1852 and September 1853. Woodcourt is a kind-hearted "sea-going doctor" whose concern for the poor is evident in his attempts to save Jo, the young crossing sweeper, from the oppression of disease, want, and suspicion and whose moral integrity is confirmed by his marriage to the novel's principal protagonist and narrator, Esther Summerson. ${ }^{56}$ In one particularly notable passage, Dickens depicts a conversation between Esther and the eccentric Miss Flite. Having recovered from a near-fatal case of smallpox, Esther is informed by Miss Flite that her beloved Woodcourt has been involved in a shipwreck in the "East-Indian seas." Having allayed her fears as to Woodcourt's safety, she then proceeds to recount the details of that "awful scene": "There, and through it all, my dear physician was a hero. Calm and brave, through everything. Saved many lives . . . took the lead; showed them what to do, governed them, tended the sick, buried the dead, and brought the poor survivors safely off at last! My dear, the poor emaciated creatures all but worshipped him. They fell down at his feet, when they got to the land, and blessed him. The whole country rings with it." ${ }^{57}$ Once again, however, Woodcourt's story only serves to highlight the relative neglect of medical heroism. Thus, when Miss Flite states that "my brave physician ought to have a Title bestowed upon him. And no doubt he will. You are of that opinion?" Esther replies, "That he well deserved one, yes. That he would ever have one, no": "I said it was not the custom in England to confer titles on men distinguished by peaceful services, however good and great; unless occasionally, when they consisted of the accumulation of some very large amount of money." 58

As Lauren Goodlad's reading of Bleak House suggests, this passage, and the character of Woodcourt more generally, embodies many of the tensions and ambiguities inherent in contemporary medical rhetoric and in understandings of the relationship between professionalism and the state. Woodcourt's actions may be heroic, even manly, but they do not conform to a conventionally militaristic model. On the contrary, Esther explicitly refers to them as "peaceful services." Thus, while

\footnotetext{
54 "Heroism of the Clergy and Medical Men," The Times, 14 August 1847, 7; "Suum Cuique," "Letter to the Editor: Poor-Law Medical Remuneration," Lancet 50, no. 1265 (27 November 1847), 584.

${ }^{55}$ Fred Kaplan, Dickens: A Biography (London, 1988), 148, 262-63; Lauren M. E. Goodlad, "Is There a Pastor in the House? Sanitary Reform, Professionalism and Philanthropy in Dickens' MidCentury Fiction," Victorian Literature and Culture 31, no. 2 (September 2003): 525-53; Socrates Litsios, "Charles Dickens and the Movement for Sanitary Reform," Perspectives in Biology and Medicine 46, no. 2 (Spring 2003): 183-99; P. Gilbert, "Medical Mapping: The Thames, the Body and Our Mutual Friend," in Filth: Dirt, Disgust, and Modern Life, ed. William A. Cohen and Ryan Johnson (Minneapolis, 2005), 78-102.

${ }^{56}$ Charles Dickens, Bleak House (London, 1853), 451.

${ }^{57}$ Ibid., 351.

${ }^{58}$ Ibid., 352.
} 
Woodcourt accords with the type personified by Sidney Bernard or Dr. Cunningham, his identity hovers awkwardly between a militaristic ideal of intrepidity and action and the domestic virtues of compassion and humanity. This tension between militarism and domesticity also reflects a broader tension in Dickens's work between what Goodlad identifies as a liberalist pastorship and a more utilitarian statism. At the heart of Dickens's narrative is a critique of what The Times would soon refer to as the "system," a social and governmental apparatus in which those with wealth and connections thrived, while men of industry and ability did not. This contrast between the activity of men such as Woodcourt and the idleness and insularity of aristocratic parliamentary politics is brought into even greater relief by the ironic use of the shipwreck as a metaphor to describe the state of the country in a conversation between Lord Boodle; William Buffy, MP; and Sir Leicester Dedlock. ${ }^{59}$ In this sense, Dickens's text paralleled a reformist medical rhetoric that purposefully conflated individual acts of heroism with the more general claims of lower-status medical practitioners to state recognition, reward, and authority. And yet in many ways, Woodcourt does not conform to the model of disinterested professional expertise advanced by medical radicals and personified by his friend Southwood Smith. Goodlad notes, for example, the geographic and conceptual distance between Woodcourt's actions and the more immediate concerns of sanitary reform. She claims that "Dickens neither installs Woodcourt in the civil service or military, nor depicts him as citizen-advocate for local or voluntary sanitary improvements." ${ }^{00}$ Thus, while Dickens clearly recognizes the complaints of medical practitioners concerning their lack of recognition and the inefficiency of governmental authority, he falls short of advocating a form of state service akin to the military. Dickens's hero (for Woodcourt is nonetheless a hero) is no dispassionate agent of state power; he is, instead, a compassionate agent of pastoral care.

\section{CRIMEAN COMPLEXITIES}

This complex and occasionally ambivalent fusing of the medical and the military was to play an especially important role in the shaping of medical masculinities during and immediately after the Crimean war (1854-56). Although one commentator has claimed that the Crimea represented "a watershed in civil-military relations" that would propel the army to the forefront of Victorian popular consciousness, others have shown how it was marked by an antiaristocratic critique of military incompetence, fueled by the reporting of William Howard Russell in The Times, and sustained by the Administrative Reform Association (of which Dickens was an active member). ${ }^{61}$ It is only possible to reconcile these two apparently contradictory perspectives by considering the wider cultural significance of the Crimean war. It certainly did provoke a debate about the values and abilities of the aristocracy versus those of the middle and commercial classes that, conjoined

\footnotetext{
${ }^{59}$ Bemoaning the limited possibilities of political preferment, Lord Boodle complains to Sir Leicester Dedlock that "the country is shipwrecked, lost, and gone to pieces" (ibid., 113).

${ }^{60}$ Goodlad, "Is There a Pastor in the House?" 535-38.

${ }^{61}$ John Winifred Martin Hirschberger, Images of the Army: The Military in British Art, 1815-1914 (Manchester, 1988), 49. Anderson, "Administrative Reform Association"; Markovits, Crimean War, chap. 1.
} 
with the ostensibly meritocratic recommendations made by the Northcote-Trevelyan Report on the Civil Service (1853-54), constituted perhaps the greatest challenge to aristocratic hegemony in Victorian Britain. ${ }^{62}$ And yet the very absence of appropriately heroic figures among the political and military leadership served in many ways to raise the popular profile of the army as the public came to valorize the bravery and fortitude of the common soldier. If the Crimea was, to quote The Times, a "people's war," then it was also very much a soldiers' war. ${ }^{63}$ From the "Thin Red Line" of Balaclava to the "Soldier's Battle" of Inkerman, it was subalterns, noncommissioned officers, and private soldiers who were generally credited with snatching victory from the jaws of defeat, a "democratization" of heroism that was most clearly expressed by the inauguration of the Victoria Cross (1856) as an award for valor, regardless of rank. ${ }^{64}$

Similar currents also served to shape the cultural representation of medicine during the war. Although health care provision in the East was manifestly inadequate and the Army Medical Department one of the most heavily criticized of the war, the Crimea also produced a number of medical heroes whose individual acts of courage and self-sacrifice functioned as a synecdoche for the professionalism and ability of army medical personnel in the face of routine administrative incompetence. Today the best-known figure associated with medicine in the Crimea is undoubtedly Florence Nightingale. However, while Nightingale's reforms of the Scutari hospital were certainly well covered in the contemporary medical press, her subsequent fame has served to obscure a number of equally celebrated army surgeons whose heroism, unlike the maternal (or matriarchal) Nightingale, were more in keeping with established masculine conventions. ${ }^{65}$ Around fifty-four such individuals lost their lives during the campaign, and three were subsequently awarded the Victoria Cross. ${ }^{66}$

Perhaps the most famous of all was Dr. James Thomson, assistant surgeon in the 44th Regiment. Left behind for nearly five full days after the battle of the Alma to care for around 750 wounded Russians in the face of potential attack from Cossack units, Thomson saw the survivors onto the HMS Albion, only to die from cholera just over two weeks later. ${ }^{67}$ Thomson's name resounded throughout the medical press. In October 1854, the Lancet asked: "But what is to be said

\footnotetext{
${ }^{62}$ Lauren M. E. Goodlad, Victorian Literature and the Victorian State: Character and Governance in a Liberal Society (Baltimore, 2003), chap. 4.

${ }^{63}$ The Times, 5 May 1854, 8.

${ }^{64}$ Melvin Charles Smith, Awarded for Valor: A History of the Victoria Cross and the Evolution of British Heroism (Basingstoke, 2008). See also Edward M. Spiers, The Army and Society, 1815-1914 (London, 1980); Matthew Paul Lalumia, Realism and Politics in Victorian Art of the Crimean War (Ann Arbor, MI, 1984); and Stefanie Markovits, "'North and South,' East and West: Elizabeth Gaskell, the Crimean War, and the Condition of England," Nineteenth-Century Literature 59, no. 4 (March 2005): 463-93.

${ }^{65}$ Poovey, Uneven Developments, chap. 6; Markovits, “'North and South,' East and West,” 485-91, and Crimean War.

${ }^{66}$ These men were Thomas Egerton Hale, assistant surgeon in the 7th Fusiliers (Sebastopol/Redan, 8 September 1855); James Mouat, surgeon in the 6th (Inniskilling) Dragoons (Balaclava, 26 October 1854); and William Henry Thomas Sylvester, assistant surgeon in the 23rd Regiment (Sebastopol/ Redan, 8 September 1855).

67 "Our Special Correspondent" (William Howard Russell), "The War: The British Expedition," The Times, 20 October 1854, 7, and 23 October 1854, 7.
} 
of the heroism required to face death in the thousand forms in which it must have presented itself to the mind of that lonely man? . . . We answer that, let the deeds done by others in that gallant army be what they may, none are more worthy of mention, or required more heroic courage and self-devotion, than this of DR. THOMSON of the 44th." 68

Such heroic imaginings extended beyond the medical sphere. Not only were Thomson's actions reported in more general accounts of military heroism, but two of Arabella and Louisa Shore's poems in their Crimean War Lyrics (1855) referred directly to the actions of medical men during the conflict. ${ }^{69}$ One of these, "The Brave who have not Bled," paid tribute to those who had died from disease, "Soldier and brave physician" alike, while "The Good Physician" celebrated the Thomson episode.$^{70}$ The opening stanza acknowledges the essential parity of military and medical heroism:

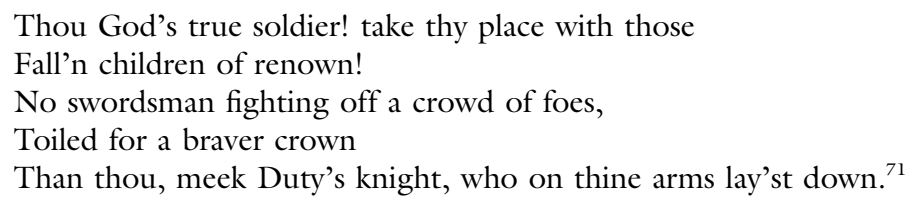

Although referring to the somewhat removed context of India, the heroism of military surgeons is likewise evident in William Makepeace Thackeray's contemporary novel The Newcomes (1854). Having made a commonplace joke at the expense of Danby Jilks, the family doctor, Colonel Thomas Newcome retracts it as being "too severe upon . . . the profession." He then apologizes by "narrating many anecdotes he knows to the credit of surgeons. How, when the fever broke out on board the ship going to India, their surgeon devoted himself to the safety of the crew, and died himself, leaving directions for the treatment of the patients when he was gone! What heroism the doctors showed during the cholera in India; and what courage he had seen some of them exhibit in action." 72

As I have suggested, however, the representation of medical heroism in the Crimea was not without its political edge. As with prewar examples, accounts of the Thomson episode, in both the medical and the popular press, were framed by grievance. Until the formation of the Royal Army Medical Corps in 1898, neither the medical officers under the command of the Army Medical Department nor the surgeons and assistant surgeons of individual regiments were accorded the status of military personnel but were technically civil officers. As such they were not entitled to the same conditions of service as their military colleagues; they held no substantive rank (and hence had no executive authority), were not entitled to servants or a pension, and were ineligible for military honors and awards. ${ }^{73}$ The

\footnotetext{
68 "Heroism and Labours of the Surgeons of the Alma," Lancet 64, no. 1626 (28 October 1854), 358.

${ }^{69}$ See, e.g., "Heroic Incidents of the War," New Monthly Magazine 103, no. 409 (January 1855), 100.

${ }^{73}$ Neil Cantlie, A History of the Army Medical Department (London, 1974), 2:3-4, 9.
} 
issue did not begin with the Crimea. In 1847, for example, the Lancet had complained that the award of medals to veterans of the Peninsula and naval campaigns during the French wars would not extend to medical men. ${ }^{74}$ Nevertheless, the Crimean campaign heightened the intensity of the debate, especially since the Lancet's rhetorical contrast between the professionalism of the middle-class army surgeon and the elitism and incompetency of "Horse-Guards" took shape within the context of a much wider critique of aristocratic inefficiency. Delivering his oration to the Medical Society of London, John Fernandez Clarke asked: "Are the services conferred upon our armies by the medical officers attached to them of less importance to the welfare, or even to the success of the troops then those rendered by generals and lieutenants? . . . Braver and more skilful men are not to be found in any country. . . . If ever a monument should be raised for great actions upon the field of battle, that monument should be raised to Thompson [sic]." Referring to the equally heroic actions of "Mr Wilson," an assistant surgeon who rallied the men of the Duke of Cambridge's division at the battle of Inkerman, Clarke pointed out that his only reward had been promotion to surgeon, claiming that "in ancient Rome, the civic crown would have been placed upon his brow; in France, he would have been decorated with the star of the Legion of Honour." Once again, then, French "meritocracy" provided a counterpoint to British governmental and military neglect, as commentators repeatedly referred to Napoleon's high estimation of military surgery and highlighted the fact that medals and other honors had been freely awarded to the medical personnel of the French army in the Crimea. ${ }^{76}$

And yet, while the anomalous status of military surgeons was clearly an object of great vexation for many medical commentators, the fact that Thomson and his ilk were, in effect, civil practitioners, merely served to strengthen the metaphorical and rhetorical associations between medical practice and militaristic heroism; if the grievances of the poor law surgeon and the military surgeon were essentially the same (lack of reward, recognition, and authority), then so too was their bravery, fortitude, and self-sacrifice. In an 1854 obituary, the Lancet therefore segued from the medical dimensions of the "Eastern Question" into those of the "Condition of England": "All the true glories of the medical profession are unostentatious. They are founded on duties performed . . . in scenes of poverty and pestilence at home, and of wounds and pain . . . amongst our gallant soldiers and sailors abroad. . . . In civil life it is the same. The medical practitioner is the slave of all. . . . If some fierce epidemic rages, and his wealthier neighbours fly for safety, he remains to encounter every danger." ${ }^{77}$ Although such connections between military

\footnotetext{
74 "The personal hazard incurred by the military surgeon is as great as that to which the rest of the troops are exposed," it argued. They "are nothing if not imbued with the true military spirit; they are frequently killed or wounded in battle . . . [and] they ought to receive their meed of honour and decoration when medals are to be worn and ribbons displayed" (Omission of Honorary Awards to Military and Naval Surgeons," Lancet 49, no. 1241 [12 June 1847], 626). See also "Summary of the Claims of the Medical Officers of the Army and Navy to Military Rewards and Distinctions," Lancet 54, no. 1360 (22 September 1849), 321-26.

${ }^{75}$ John Fernandez Clarke, "Oration Delivered before the Fellows of the Medical Society of London," Lancet 65, no. 1646 (17 March 1855), 282.

76 "Honours to Military Surgeons," Lancet 69, no. 1762 (6 June 1857), 584.

77 “Obituary," Lancet 64, no. 1632 (9 December 1854), 497; emphasis added.
} 
and civil medicine were most often deployed in relation to public health and the plight of the poor law surgeon, this obituary provides an insight into how even routine, domestic medical practice could be presented as a form of everyday heroism. After all, the practitioner being commemorated was neither a military surgeon nor a District Medical Officer but rather a seventy-one-year-old general practitioner from Market Rasen in Lincolnshire. Thus, interpolated between the established imagery of medical heroism were scenes of a more prosaic nature: "His meals, his rest, all his social comforts, are perpetually interrupted. In country practice, especially, he endures fatigue, encounters darkness and storm, is sent for at all hours on every capricious impulse of the rich. . . . His life is a continued struggle, and if he is enabled to bring up and educate a family of children, and to die solvent, he is looked upon as a favorable exception." ${ }^{78}$

Again, such associations were also evident in the wider cultural sphere. Stefanie Markovits's work considers the relatively oblique ways in which the Crimean war shaped the Victorian literary imagination. As she shows, aside from Charles Kingsley's Westward Ho! (1855), which was not, in any case, based on contemporary events, the 1850s and 1860s were remarkably free of "war novels." Instead, much contemporary literature, most notably Elizabeth Gaskell's North and South (1854$55)$, engaged with the war in a tangential manner that foregrounded the domestic concerns of poverty, labor, and social relations. ${ }^{79}$ What is even more remarkable about such literary productions, I would suggest, is the way in which medicine functioned as a point of contact between civil and military conceptions of heroism, the figure of the doctor serving as an alternative to more conventionally martial heroes. In 1868, for example, William Howard Russell published his one and only novel, The Adventures of Doctor Brady. Drawing on his firsthand experiences of the Crimean war and Indian "mutiny," it elaborated a tale of sensational adventure and daring. And yet the main hero of the story, Terrence Brady, is not a soldier, as one might expect, but rather, as the title suggests, a doctor. In a similar vein is Charles Kingsley's Two Years Ago (1857). Unlike Westward Ho!, Two Years Ago was concerned with recent events, its title referring to a time when "pestilence was hovering over us and ours, while the battle-roar was ringing in our ears." The hero of the novel is Tom Thurnall, a manly and intrepid doctor who, after traveling the globe and surviving all manner of life-threatening situations, is shipwrecked off the Devon coast. Rescued by the beautiful and pious local schoolteacher, Grace Harvey, Tom remains in the village of Aberalva, which he proceeds to deliver from an outbreak of cholera before volunteering for service in the Crimea, where he is followed by the Nightingale-esque Grace. Kingsley's novel thus conflates the heroism of sanitary medicine with the heroism of military adventure. As Kristine Swenson has argued, the cholera outbreak in Aberalva "becomes a training ground and metaphorical equivalent for heroisms that characters will perform in the Crimea." ${ }^{81}$ This association between medical and military masculinities is further enhanced by Tom's friendship with the like-minded Major Campbell, while his active and intrepid character as a "man of action" is juxtaposed

\footnotetext{
${ }^{78}$ Ibid.

${ }^{79}$ Markovits, "'North and South,' East and West," and Crimean War, chap. 2.

${ }^{80}$ Charles Kingsley, Two Years Ago, 6th ed. (London, 1889), 1.

${ }^{81}$ Kristine Swenson, Medical Women and Victorian Fiction (Columbia, MO, 2004), 44.
} 
to the weak effeminacy of Elsley Vavasour, an aspirant "Spasmodic" poet. ${ }^{82}$ In her reading, Swenson suggests that the book's "conflation of a cholera epidemic and the war would likely have seemed quite natural to a Victorian looking back upon 1854-5, for a cholera epidemic did, in fact, plague England in the summer months of 1854 , just as in the novel." ${ }^{83}$ Perhaps, but such claims neglect some of the more subtle imaginative associations at play here. As Markovits notes, both Doctor Brady and Two Years Ago are complex works, characterized by rhetorical evasion and "generic discomfort." In Doctor Brady in particular, there is a profound ambiguity in the protagonist's characterization, with Russell "repeatedly reminding [the reader] that Terrence would rather have been a soldier." ${ }^{" 84}$ It is almost as if Russell was unsure how exactly to represent a form of noncombatant heroic manliness. In this sense, both novels suggest that medicine provided an important imaginative resource for the construction of a midcentury middle-class masculinity that somehow married militaristic visions of heroism with a more domesticated cult of activity. At the same time, however, they also testify to the indeterminacies of medical professional identity, oscillating between the domestic and the warlike and yet never totally comfortable in either.

I opened my analysis by suggesting that medical discourses of militarism and heroic masculinity were tied to a wider reformist agenda that sought greater state reward, recognition, and authority, not simply for District Medical Officers but, more generally, for those lower-status general practitioners and provincial medical men who were excluded from the centers of corporate power. The question therefore remains as to how successful this harvesting of heroism's "symbolic capital" was in more explicitly political terms. Of course it is almost impossible, not to say historically naive, to establish a direct causal relationship between metaphor and rhetoric on the one hand and political and legislative developments on the other. Yet it is remarkable that the 1850s, the decade that saw the flowering of a discursive and representational culture of militarized medical masculinity, also witnessed the passage of perhaps the most important piece of legislation relating to the medical profession in nineteenth-century Britain, the 1858 Medical Act. As in the literary sphere, medical reformers used the experiences of the war to reflect on the conditions of metropolitan practice. Relating the findings of the 1856 Select Committee on the Medical Department of the Army to the concerns of his colleagues, for example, Richard Griffin of the Poor-Law Medical Reform Association claimed that "history teaches us that most of the calamities affecting nations arise from the first complaints of individuals being unheeded by those in authority. . . . The sufferings of our army in the Crimea are so fresh in our memory that it needs no other example. I pray you therefore no longer to disregard the complaints of your medical officers, in whom you have reposed a solemn trust-the care during sickness of no less than four millions of the labouring classes of this great kingdom." ${ }^{85}$ Medical reformers were at least moderately successful in pressing their case. Not

\footnotetext{
${ }^{82}$ Kristie Blair, "Spasmodic Affections: Poetry, Pathology and the Spasmodic Hero," Victorian Poetry 42, no. 4 (Winter 2004): 485-86.

${ }^{83}$ Swenson, Medical Women, 44; emphasis added.

${ }^{84}$ Markovits, Crimean War, 41. See also Pamela K. Gilbert, Cholera and Nation: Doctoring the Social Body in Victorian England (Albany, NY, 2008), chap. 8.

${ }^{85}$ Richard Griffin, "Letter to the Editor: Poor-Law Medical Reform Association," Lancet 70, no. 1774 (29 August 1857), 232.
} 
only were the terms of poor law medical service generally improved during this period, but the Medical Act, with its establishment of the Medical Register and General Medical Council, granted the profession the state recognition and powers of effective self-governance that many had demanded. ${ }^{86}$

The imaginative and political appeal of the military paradigm, therefore, ensured that it continued to play a prominent role in medical rhetoric throughout the later 1850s and 1860s. This was particularly true of the preliminary addresses given to first-year medical students. As pedagogical and rhetorical tools designed to initiate students into the values of the profession, such lectures provide an invaluable insight into contemporary medical culture. As well as looking back to the experience of the Crimea, medical lecturers elaborated new heroic figures, especially those who had been forged in the masculine sphere of conflict. One notable example was David Herbert Llewellyn, assistant surgeon on board the Confederate States Navy's commerce-raider Alabama. Having been engaged by the USS Kearsarge off the French coast, Llewellyn tended to the wounded and, when the order came to abandon ship, refused to go aboard the lifeboat until all of his patients had been evacuated. He drowned when the ship went down and was later awarded the Confederate Medal of Honor. Llewellyn was a Briton, born in Wiltshire and educated at Charing Cross Hospital medical school. ${ }^{87}$ Such links between a medical school and the heroic actions of a former pupil held great imaginative appeal for new students. Thus, the students and staff of the Charing Cross school erected a granite tablet to Llewellyn (fig. 1), while St. Thomas's found its own hero in Edward Chaffers, who, "actuated by laudable motives, proceeded to the Southern States of America," where he became acting chief surgeon of Hume's Cavalry Division. ${ }^{88}$ But of course the resonance of such actions was not confined to the schools in which they had studied. Addressing the pupils of the Manchester Royal School of Medicine in 1864, for example, Mr. Stone cited Llewellyn's actions and those of the Crimean surgeons as testament to the fact that "benevolence, heroism, [and] duty formed the tricolour of the medical profession." 89

As with the period before the Crimea, medical lecturers of the late 1850s and 1860s not only sought to use cases of individual heroism as exemplars of general medical character but also transposed the experience of war onto the profession as a whole through the imaginative amalgamation of civil and military practice. In addressing his pupils at the London Hospital, Dr. Barnes suggested that medicine was "one ceaseless battle to counteract the life-invading influences that men raise against each other." In this sense he perpetuated the vision of medicine as a form of middle-class moral reform directed against both working-class culture and

\footnotetext{
${ }^{86}$ Hodgkinson, Origins of the National Health Service, chap. 12.

87 "The Surgeon of the Alabama," The Times, 24 June 1864, 12; "Medical Annotations: The Surgeon of the Alabama," Lancet 83, no. 2130 (25 June 1864), 730; “The Surgeon of the Alabama,"Lancet 83, no. 2131 (2 July 1864), 18; W. W. Morgan, "Letter to the Editor: The Surgeon of the 'Alabama,'” Lancet 83, no. 2132 (9 July 1864), 43; "London: Saturday, June 25, 1864," Illustrated London News 44, no. 1265 (25 June 1864), 610; “The Fight between the Alabama and the Kearsarge," Illustrated London News 45, no. 1266 (2 July 1864), 2, 7; “The Surgeon of the Alabama," Illustrated London News 45, no. 1267 (9 July 1864), 41.

${ }^{88}$ Edward Clapton, "St Thomas's Hospital: Introductory Address," Lancet 84, no. 2145 (8 October 1864), 411, and "Introductory Lectures: St Thomas's Hospital," British Medical Journal 2, no. 197 (8 October 1864), 412 .

${ }^{89}$ Clapton, "Introductory Lectures," 414.
} 


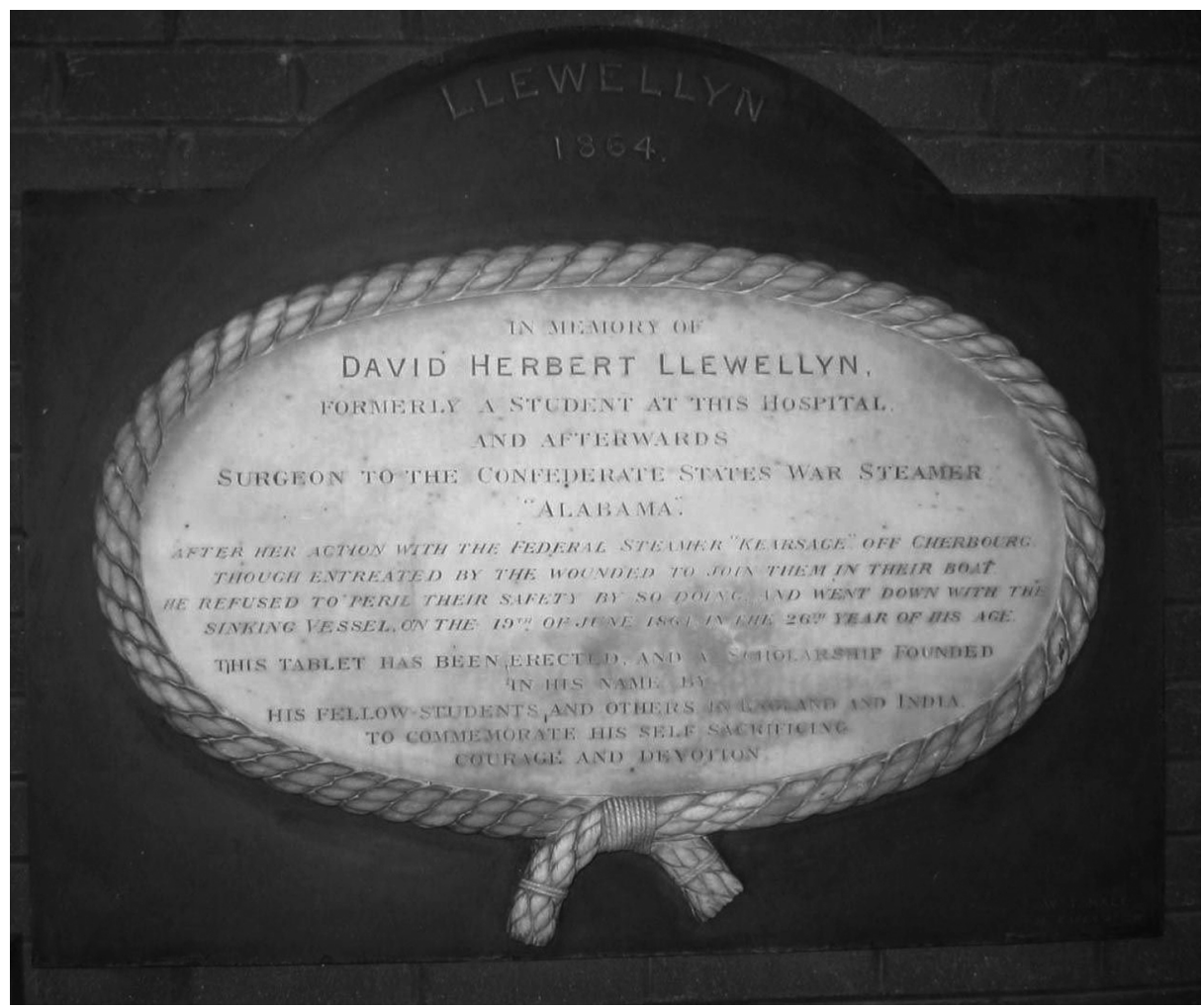

Figure 1-Memorial to David Herbert Llewellyn at Charing Cross Hospital, London (courtesy of Clare Hickman).

the inefficiency of aristocratic government. Referring to poor sanitation, industrial accidents, and alcohol abuse as "the evils we have to combat in civil life," he stated that "from this scene, the mind follows the surgeon to the field of battle . . . [where] he has to avert or to quell the diseases that spring from ignorance and neglect, as well as to repair the injuries inflicted by the destructive engines of war." ${ }^{90}$ At its most fundamental, the militarization of medical culture entailed the repeated use of martial analogies to describe the relationship between medicine and illness. Languages of "combating," "battling," or "fighting" disease abounded in this period. For example, Dr. Anstie of the Westminster Hospital compared the "practical physician" to a "man who fights in the gloom of twilight with foes who seem innumerable," while Dr. Braxton Hicks of Guy's employed an elaborate military analogy to describe changes in therapeutic practice: "In former times . . . disease was a great entity; inflammation a violent enemy who would to a certainty destroy us if we did not kill him, and the patient was made the neutral ground. . . . Now we rather look upon the patient as a beleaguered city: we throw in our

\footnotetext{
${ }^{90}$ Robert Barnes, "Introductory Lecture Delivered at the Opening of the London Hospital Medical College, Session 1860-61," Lancet 76, no. 1936 (6 October 1860), 326.
} 
supplies from time to time, leaving the garrison to fight it out, and as long as it is equal to the contest, we do not sap its supplies by adding to its numbers."

To a great extent, such discourses were shaped by the wider cultures of a bellicose imperialism and nationalism that emerged in the wake of the Indian "mutiny" and that were enhanced by the French invasion scare and volunteer movement of 1859-60. Against such a backdrop, medical rhetoric could not but imbibe the languages and ideologies of an aggressive militarism. Thus, in a remarkable speech to the first-year medical students of the London Hospital in November 1859, George Critchett opened with an imaginative flourish, comparing such annual addresses to other historic gatherings in which the people combined "to carry out some great national cause or avert some great national calamity." Critchett's allusion to the French menace would have been clear to his audience as he imagined "what a huge national assemblage there would be if the foot of the rash invader were ever to be placed on [our] free and sacred soil; how Britain would rush in her might, and be as one to arm, to repel and to crush." Framed though it was by contemporary events, Critchett's warlike imagery was not simply a cheap sop to popular jingoism. Instead, it inflected the tone of his entire speech, as war, empire, and medicine were fused into a seamless vision of national service and self-sacrifice. Beginning with the field of sanitary medicine he claimed that "it is now universally admitted that our profession is carrying on a noble work. . . . Disease [is] combated and suffering allayed . . . pestilence is traced to its lurking places and the laws of health are explained and enforced. The important body of men who are toiling to accomplish all this are diminishing in number. . . . Going forth in the spirit of a missionary, they sometimes encounter the death of a martyr." With the image of the missionary providing an imaginative link between the domestic and imperial contexts, Critchett then proceeded to represent war and empire as medicine's guiding mission: "It is an important and interesting day, when our country sends up fresh recruits to fill up the ranks of our profession, and to meet the increasing demands of our army, our navy, our merchants' service, and of those vast and numerous colonies upon which it is said the sun never sets. It is this fresh infusion of young life, and vigour, and enthusiasm that from year to year renews and sustains our profession." ${ }^{92}$ For some commentators, therefore, the rise of imperialism and nationalism allowed them to reframe medicine as a form of quasimilitary service. For others, however, the relationships among medicine, war, and empire, never exactly straightforward, were rendered even more ambivalent and complex by this turn of events.

I have already suggested that medical invocations of a militarized masculinity often served to highlight the discrepancy between a popular estimation of medical sacrifice and that of military glory. I have also suggested that they embodied an essential tension between the humanitarian and domestic values of care and the military values of conquest and destruction. From the late 1850s onward, these tensions came increasingly to the fore, shaping a distinct and alternative strand

\footnotetext{
${ }^{91}$ Francis Edmund Anstie, "Westminster Hospital: Inaugural Address," Lancet 80, no. 2040 (4 October 1862), 368. John Braxton Hicks, "Introductory Lecture Delivered at the Opening of Guy's Hospital Medical School, Session 1864-65," Lancet 84, no. 2145 (8 October 1864), 368.

${ }_{92}$ George Critchett, "Introductory Lecture Delivered at the London Hospital Medical School at the Commencement of the Session 1859-60," Lancet 74, no. 1891 (26 November 1859), 527.
} 


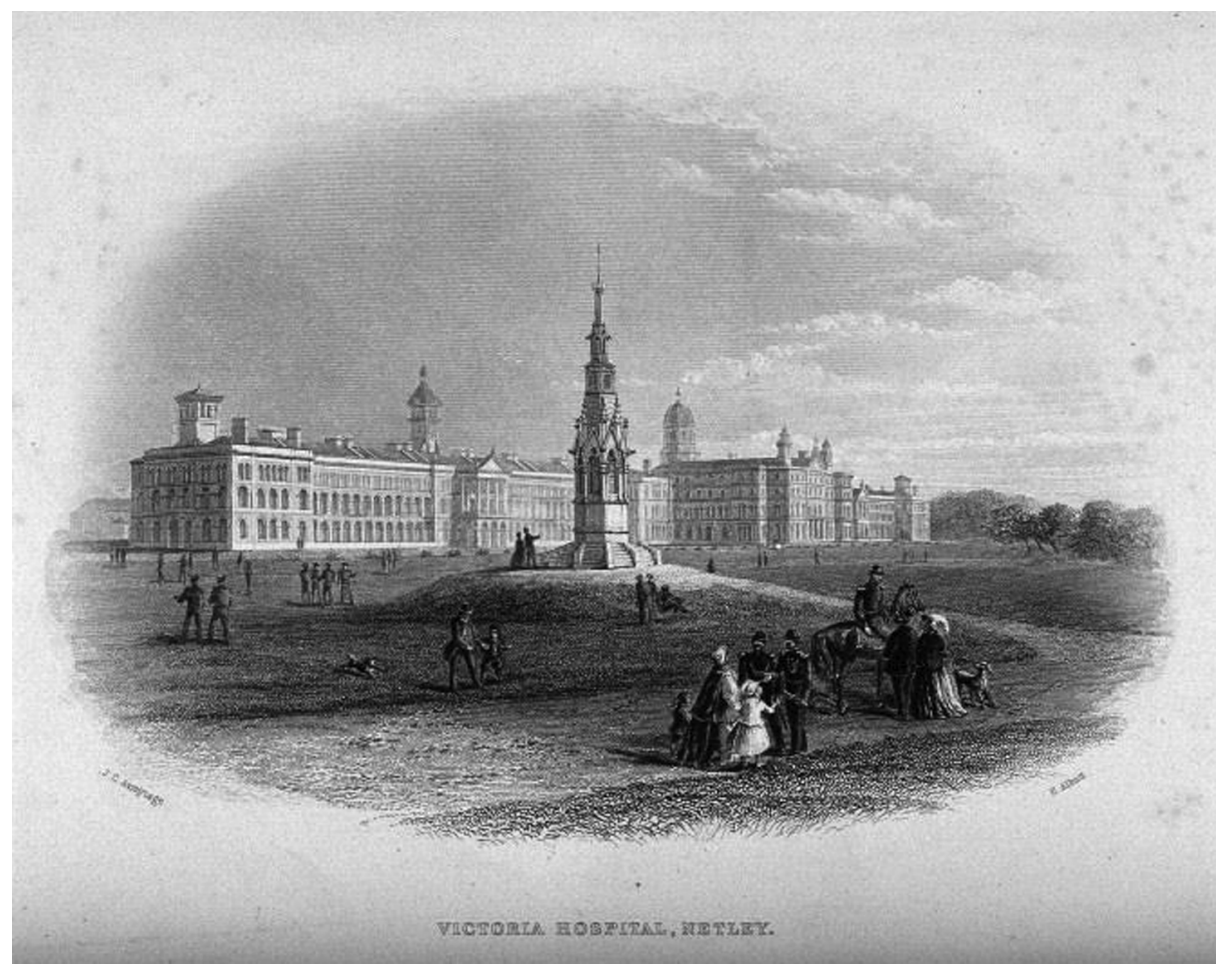

Figure 2-Memorial to the medical practitioners of the Crimean war at Victoria Hospital, Netley, Hampshire. Line engraving by E. Albutt after J. C. Armytage (Wellcome Library, London).

within medical discourse to sit alongside the warlike imaginings of men like Critchett.

Many medical practitioners were frustrated by what they saw as the continued neglect of medical service and the ambiguous position of noncombatant heroism in a society increasingly obsessed with martial values. Even in the military sphere, the Crimean war had done little to improve the status of army surgeons. In 1864, a monument to the medical practitioners who had served and died in the Crimea was unveiled at the new military hospital at Netley, near Southampton (fig. 2).$^{93}$ The London Review noted that the monument had "been somewhat long in coming," hoping that it would "make reparation to the medical profession for the stupid contempt with which combatant officers in the army, much to their own discredit, affect to non-combatants." ${ }^{\prime 44}$ But as it acknowledged, this gesture belied the fact that medicine still occupied a markedly inferior position within the military, so much so in fact that many vacancies in the Army Medical Department and Naval and Indian Medical Services remained unfilled. "Can we wonder at such results," it asked, "when both in the army and the navy gentlemen of education, naturally proud of their noble profession, find themselves treated as inferiors?" 95

\footnotetext{
${ }^{93}$ The monument was demolished in 1973.

94 “Honour to 'Non-combatants,"” London Review 9, no. 214 (6 August 1864), 146.

${ }^{95}$ Ibid.
} 
The same was true of civil medicine. Despite the apparent successes of poor law medical reform and the Medical Act, many practitioners remained deeply unsatisfied, perceiving the act's provisions to be compromised and the state's recognition of medicine grudging and halfhearted. One especial grievance was that, while the act may have recognized the parameters of "orthodox" medicine in the form of the Medical Register, it did nothing whatsoever to protect the profession (and, they would claim, the public) from the depredations of "unlicensed" and "incompetent" practitioners. ${ }^{96}$ Thus, rather than enhancing the prestige of medicine, this "martial vision" only served to highlight how little it had gained by comparison. What had always been a fragile imaginative association had now, for some at least, become untenable. In commenting on the limitations of the Medical Act, one correspondent to the Lancet stated that "we English are, doubtless, a fine people in most things. . . . First in arms . . . and in commerce, the glorious symbol of our liberty and strength floats on every ocean, and waves in every breeze of the wide world." However, "when we look nearer to home, we find a worm at the very pith of this magnificent tree; and, as regards the protection of human life from the ravages of quackery and imposture, the dismal banner of the death'shead and cross-bones would best symbolize the . . . care of the State." 97

In some cases, this discontent and frustration served to shape a novel humanitarian discourse in which commentators posited medicine in contradistinction to the military endeavor, asserting the moral supremacy of their own profession. Such discourses crystallized in the debates that surrounded the erection of a statue to Edward Jenner in Trafalgar Square. During the middle decades of the nineteenth century, the square had become the premier metropolitan space for the commemoration of British military and imperial glory. ${ }^{98}$ Nelson's Column had been unveiled in 1843 and was followed by statues to Sir Charles Napier (1855) and Henry Havelock (1861). ${ }^{99}$ The inauguration of the statue to Jenner in May 1858 was therefore opposed by many who thought its positioning inappropriate. In Parliament, the radical MP Thomas Duncombe asked whether the statue might be moved, claiming that although he "did not mean to say that a statue of Dr Jenner was not a very good thing in its proper place . . . he thought it was altogether out of place among statues of our naval and military heroes." If the government would not move it, he hoped that "some independent Member would move an Address to the Crown for the removal of the statue of this promulgator of the cowpox-nonsense from its position in Trafalgar Square." 100 Duncombe's opposition to compulsory vaccination (although not to vaccination per se) may well have informed his opposition, as may have his prior service in the army. Nevertheless, similar sentiments were expressed in a somewhat more sober tone in The Times.

\footnotetext{
${ }^{96}$ Michael Brown, "Medicine, Quackery and the Free Market: The 'War' against Morison's Pills and the Construction of the Medical Profession, c. 1830-c. 1850," in Medicine and the Market in England and Its Colonies, c. 1450-c. 1850, ed. Mark S. R. Jenner and Patrick Wallis (Basingstoke, 2007), 238-61.

${ }^{97}$ Henry Holmes, "Letter to the Editor: Medical Registration versus Medical Squabbles," Lancet 72, no. 1833 (16 October 1858), 408.

${ }^{98}$ Rodney Mace, Trafalgar Square: Emblem of Empire (London, 1976).

${ }^{99}$ Deborah Cherry, "Statues in the Square: Hauntings at the Heart of Empire," Art History 29, no. 4 (September 2006): 660-97.

${ }^{100}$ Thomas Duncombe, Speech to the House of Commons, 10 May 1858, Parliamentary Debates, Commons, 3rd ser., vol. 150 (1858), col. 354.
} 
Referring to the existing statue of Napier and the planned statue of Havelock, the editor thought Jenner's positioning beside these "two great soldiers" a "ridiculous juxtaposition." "The expense of removing this unfortunate statue of DR JENNER to some more suitable position," The Times concluded, "can only be very trifling, and we earnestly trust that the public authorities will not insult the commonest feelings of taste and propriety by leaving it where it is now placed."101

Needless to say, many medical practitioners were outraged by such statements, not least because Jenner embodied much of what they held dear concerning medicine's contribution to the "public good." The British Medical Journal wondered whether foreign subscribers to the Jenner monument would "sneer at the civilization of these islanders, who think the statue of a Napier is polluted by such company-who scornfully think that a hero who triumphed over a loathsome disease is not worthy to sit at the feet of the hero of the Scinde." "We see no reason whatever," it asserted, "that the finest site in Europe should be appropriated to the effigies of soldiers only. Why should those who destroy be ever placed in the front rank, whilst the philanthropist and the philosopher are only permitted to occupy out-of-the-way corners in forgotten squares." ${ }^{102}$ Similarly, in his speech to the Bristol and Bath branch of the British Medical Association, James George Davey told his audience that, on a recent trip to London, he had "strolled through Trafalgar Square" and, gazing on the statues there, had asked himself what future generations would think of Jenner "side by side with Nelson and Napier-the medical philosopher and public benefactor, side by side with fighting men-with the heroes of Trafalgar and the Scinde. . . . Is not the one for all time-the others named but for a period? The name of Jenner will, in the long time yet to come, be associated with a sound and progressive civilization; the names of Nelson and Napier, with but blood and rapine." 103

\section{FROM INTERNATIONALISM TO NEW IMPERIALISM}

By the late 1850s and 1860s, then, the military paradigm occupied a deeply ambiguous place within medical discourse. On the one hand, comparisons with the army figured medicine as an equivalent form of national service and underwrote a reformist agenda for the state recognition and regulation of medical practice that achieved at least partial success with the passage of the 1858 Medical Act. On the other hand, the cultural ascendancy of the military in mid-nineteenthcentury Britain also served to open up an imaginative gulf between medicine and war, with some practitioners articulating a humanitarian discourse in which the heroism of medicine did not so much mirror that of combat as occupy a superior moral plane to it. In this final epilogic section, I want to trace these tensions

\footnotetext{
${ }^{101}$ The Times, 3 May 1858, 8. Even though it was not erected until 1861, it seems that the statue of Havelock had been planned since at least 1858 .

102 "Where Shall We Place the Statue of Jenner?" British Medical Journal 1, no. 72 (15 May 1858), 395; emphasis added.

${ }^{103}$ James George Davey, "Transactions of Branches: Bath and Bristol Branch, President's Address," British Medical Journal 1, no. 139 (27 August 1859), 699; emphasis added. Despite some public support for the statue, e.g., "A Grumbler," "Trafalgar Square," Fraser's Magazine for Town and Country 58, no. 344 (August 1858), 158-60, it was moved to Kensington Gardens in 1862, where it remains to this day.
} 
through to the end of the century, sketching, in a necessarily brief and speculative manner, the ways in which these cultures of medical identity-the one overtly masculine, the other more domestic and feminine-played out against the backdrop of wider political circumstance.

If, as is generally accepted, the 1850s witnessed the beginnings of a popular militarism in Britain, then it should be remembered that attitudes toward war were also tempered by events at an international level. As John MacKenzie has suggested, one of the factors that promoted positive attitudes toward the army was the fact that, after the Crimea, most of the conflicts in which Britain engaged were small colonial wars against relatively technologically unsophisticated opponents. Not only did this present "the image of war, without its guilt and only five-and-twenty per cent of the danger," but in the wake of the Indian "mutiny," it also sustained a vision of military conquest and subjugation as a moral endeavor, an exercise in the dissemination of civilization and "international law." ${ }^{104}$ And yet if colonial conflict was celebrated within contemporary journalism, music, and juvenile literature, war between western powers occupied a rather different psychological and imaginative space. ${ }^{105}$ The battle of Solferino (1859) and the American civil war (1861-65) had demonstrated the horrendously destructive potential of conflict between equivalent belligerents, casting it in a different moral light to that between imperial armies and their colonial enemies. Alongside the celebratory rhetoric of medicine and empire that characterized addresses to medical students, the later 1860 s and 1870s therefore witnessed the development of that discourse in which the humanitarianism of medicine was situated in direct opposition to the horrors of modern warfare.

This development undoubtedly owed much to the fact that medicine itself took a leading role in international efforts to mitigate the effects of conflict. In 1863 Henry Dunant and Gustave Moynier founded what would become the International Committee of the Red Cross, the coordinating body for a network of voluntary organizations providing supplementary medical assistance in times of war. In the following year, the representatives of fourteen European countries signed the Geneva Convention, guaranteeing the neutrality of wounded soldiers and medical personnel. During the Franco-Prussian war (1870-71), numerous British medical practitioners attached themselves either to the medical services of the French or "German" military or to volunteer organizations. However, whereas in the American civil war men such as David Llewellyn and Edward Chaffers had served as cobelligerents, Llewellyn going down with his ship and Chaffers sporting a "scar in the face made by a Federal sabre at Shelbyville," those who volunteered in the Franco-Prussian conflict, distinguished by their Red Cross brassards, did so in a neutral capacity, treating the wounded of both nations and regularly crossing between the contending sides. ${ }^{106}$

Combined with an increased internationalism in medical research and practice, the foundation of the Red Cross, the signing of the Geneva Convention, and the experience of the Franco-Prussian war therefore appeared to presage a new era of

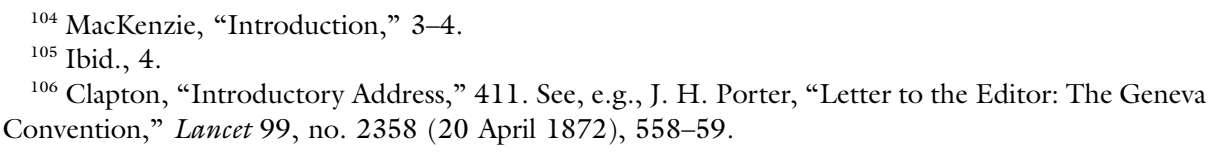


international humanitarianism that placed medicine legally, morally, and imaginatively above the militaristic concerns of nationalism and imperialism. ${ }^{107}$ During the 1870s, the British medical press often contrasted medicine's humanitarian mission with the brutality of war. This was particularly true of the Russo-Turkish conflict (1877-78), in which tales of the "Bulgarian Horrors" provoked popular outrage and provided a political platform for William Gladstone's moralistic and internationalist liberalism. ${ }^{108}$ As Patrick Joyce has argued, Gladstone's rhetoric placed women at the heart of the body politic. Their "warmth and softness," he suggests, allowed Gladstone to transcend the abstractedly political and to address an essential humanity "bound by a love women had a peculiar knowledge of, and overseen by God in his providential wisdom." ${ }^{109}$ The parallel development of the Red Cross can be said to have embodied a similarly domesticated and feminized vision of medicine, in which compassion and mercy stood opposed to violence and destruction.

In reality, however, this moment of international humanitarianism seems to have been relatively short-lived. For all his criticisms of Benjamin Disraeli's aggressive foreign policy, Gladstone's moderate and militarily temperate administration collapsed in 1885 amid the fiasco surrounding the death of General Gordon at Khartoum. Moreover, despite the policy of "Splendid Isolation," Britain's dealings in Africa contributed to rising tensions and military rivalries between the European powers. The neutrality of medicine was likewise to prove illusory. As both John Hutchinson and Bertrand Taithe have argued, rather than situating medicine above war, the formation of voluntary relief organizations actually served to harness medicine to a nationalistic project by allowing states to mobilize civilian and humanitarian resources in pursuit of strategic aims. ${ }^{110}$

By the turn of the century, therefore, an aggressive militarism once again seems to have permeated medical discourse. Nowhere was this more evident than in the coverage of the South African War (1899-1902) by the medical press. As in the Crimea, the Lancet paid regular tribute to the heroism of military medical personnel, suggesting that "never have medical officers shown greater courage and more self-sacrificing devotion to duty under trying circumstances in the battlefield than have the soldier surgeons of the QUEEN on the present occasion." "111 In the field of visual representation, too, images of the Royal Army Medical Corps and the Red Cross in South Africa frequently emphasized the bravery and daring of medical practitioners under fire, resounding in a pictorial language of "Boys" Own” masculinity (fig. 3).

\footnotetext{
${ }^{107}$ Valeska Huber, "The Unification of the Globe by Disease? The International Sanitary Conferences on Cholera, 1851-1894," Historical Journal 49, no. 2 (2006): 453-76; John F. Hutchinson, Champions of Charity: War and the Rise of the Red Cross (Oxford, 1996), 11-102. ${ }^{108}$ For an example of the medical response, see "The Medico-Political Outlook," Lancet 111, no. 2836 (5 January 1878), 18. For more on the political context, see Richard Shannon, Gladstone and the Bulgarian Agitation, 1876 (London, 1963); Patrick Joyce, Democratic Subjects: The Self and the Social in Nineteenth-Century England (Cambridge, 1994), 204-13.

${ }^{109}$ Joyce, Democratic Subjects, 206.

${ }^{110}$ Hutchinson, Champions of Charity; Bertrand Taithe, "The Red Cross Flag in the Franco-Prussian War: Civilians, Humanitarians and War in the 'Modern Age," in War, Medicine and Modernity, ed. Roger Cooter, Mark Harrison, and Steve Sturdy (Stroud, 1998), 22-47, and Defeated Flesh: Welfare, Warfare and the Making of Modern France (Manchester, 1999), 155-79.

111 “A Bright Spot in the Present War," Lancet 155, no. 3988 (3 February 1900), 319.
} 


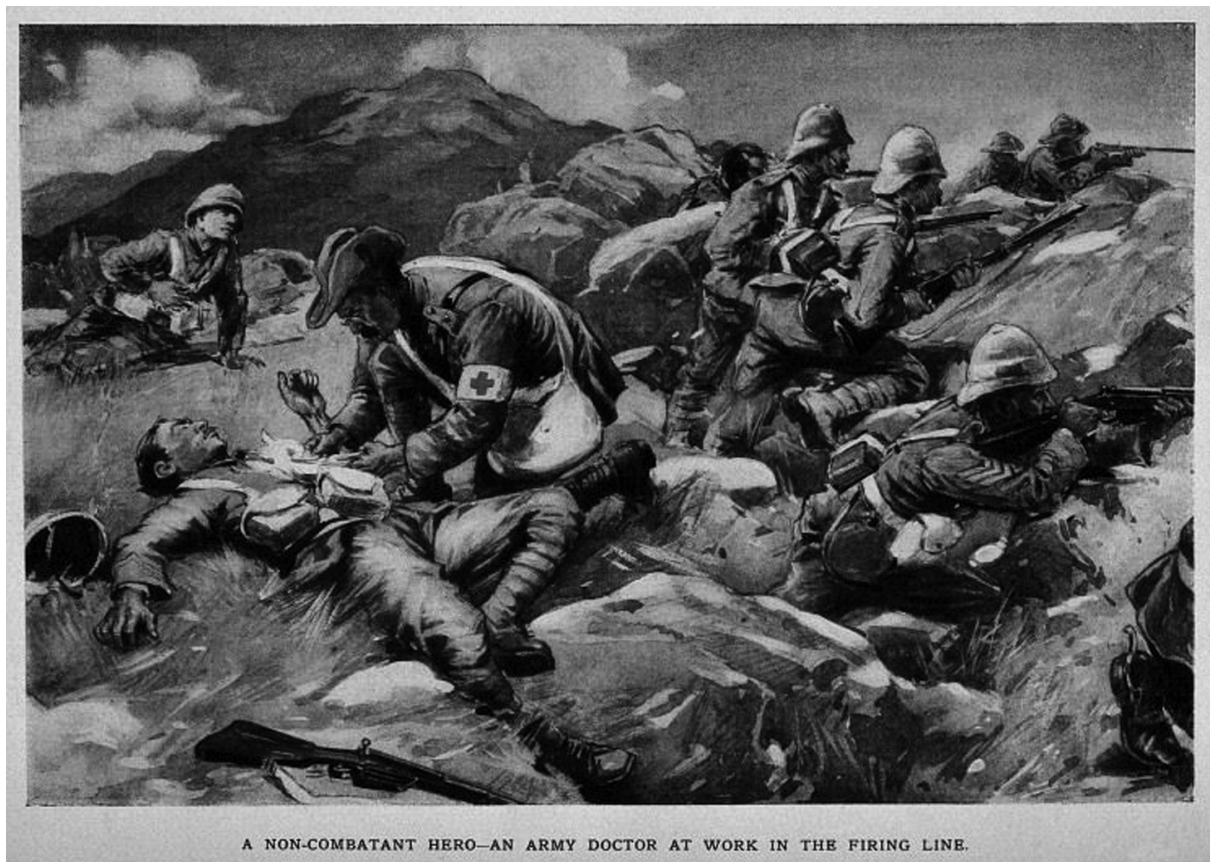

Figure 3-"A Non-combatant Hero-an Army Doctor at Work in the Firing Line" (Wellcome Library, London).

Despite the apparent similarities with the Crimea, medical discourse around the South African War differed in a subtle yet highly significant way from that of the early Victorian period. Whereas mid-nineteenth-century medical reformers had employed the trope of militarism rhetorically, to buttress claims of public service and demand greater support from the state, their late Victorian and early Edwardian successors perceived a much more intimate relationship between medicine, war, and masculinity. Speaking to the Reform Club on his return from South Africa, the surgeon Sir William MacCormac "held that the war was one of the best things that could have happened to England, because it brought out the manhood of the national character and displayed our brave bearing in evil circumstances to other nations." 112 In reality, however, the war had given rise to profound concerns about the nation's "manhood" and about the physical and moral capacities of the British soldier. In the ensuing debate about "national efficiency" and the "national physique," medicine sought to play a prominent role in preparing the country for war. ${ }^{113}$ The Lancet, for example, was an energetic advocate of compulsory military training: "It not only seems to us right that there should be some system of obligatory military training on the part of the youth and young manhood of this country but from a medical standpoint we hold that

112 “The Dinner at the Reform Club to Sir W. MacCormac and Mr. F. Treeves," Lancet 155, no. 4001 (5 May 1900), 1294.

${ }^{113}$ Geoffrey R. Searle, The Quest for National Efficiency: A Study in British Politics and Political Thought, 1899-1914 (Oxford, 1971). 
it would prove highly beneficial. The effect of a military training . . . is to strengthen the character and manliness of a people." 114 In the field of public health, too, a moralistic, even domestic, concern to redeem the poor from squalor had given way to a eugenic and avowedly militaristic desire to ensure a healthy "stock" for national and imperial defense. As $\mathrm{H}$. Beale Collins told his audience at the Home Counties Branch of the Society of Medical Officers of Health in April 1904, "The foundations of empire rest on the individual, and the permanence of an empire remains assured whilst every individual is physically and morally sound. . . Unfortunately, the improvident are so hampered by heredity, environment, and lack of opportunity, that those of their children who survive infancy and reach adult age are physically of little use for imperial purposes." 115

By taking my analysis up to the beginning of the twentieth century, it is clear that, despite an apparent continuity, a profoundly significant transformation had taken place in medical culture. For Edwardian practitioners in the decade or so before the First World War, the relationship between medicine and war had transcended the level of rhetoric and metaphor. In the debates surrounding the degeneration of the British population and the quest for national efficiency, medicine had itself become a major driving force behind the militarization of British society.

\section{CONCLUSION}

One of the purposes of this article has been to show how particularly resonant visions of masculinity might be transposed, as metaphor and ideology, across social groups and fields of practice. In analyzing the rhetorical use by medical practitioners of the tropes of militarism and heroic masculinity throughout the Victorian period, I have demonstrated both the potentials and the limitations of that endeavor. Medical practitioners, especially those employed in the state service of the poor law or in the sphere of public health, certainly did liken themselves to soldiers, fighting and dying in the face of disease. Although it was a language of comparison, which sought to appropriate the "symbolic capital" of martial heroism and intrepid masculinity, it was also very much one of contrast. The courage, devotion, and self-sacrifice of the middle-class general practitioner and District Medical Officer were shaped in opposition to the complacency, ease, and self-interestedness of the medical "aristocracy," just as the bravery and fortitude of the army surgeon were counterposed to the incompetence and inefficiency of the military hierarchy. Likewise, the popular appreciation and governmental reward of military valor were contrasted with the neglect of sanitary medicine, as medical reformers sought to represent their work in tending to the health of the laboring population as a form of state service equivalent in importance to national defense or imperial conquest. And yet despite some evident success, not only in terms of legislation and administrative reform but also, as is clear from contemporary literature, in the public imagination too, the refractive qualities of this discourse tended to dissipate some of its rhetorical force, creating tensions and ambiguities that always threatened to

\footnotetext{
114 "Lord Roberts on Imperial Defence," Lancet 166, no. 4268 (19 August 1905), 541; emphasis added.

${ }^{115}$ H. Beale Collins, "Address to the Home Counties Branch of the Society of Medical Officers of Health," Public Health 16 (October 1903-September 1904), 401.
} 
undermine it. Thus it was that while some practitioners sought to capitalize on the imaginative appeal of war and empire to shape the cultures and values of medicine, others, perceiving the army's popular ascendancy to come at some expense to themselves, articulated alternative discourses in which the humanitarian mission of medicine was presented as morally and politically superior to the baser qualities of martial valor.

Perhaps these ambiguities and contradictions should come as little surprise. Indeed, and as my brief discussion of post-Crimean literature suggests, the cultures of mid- to late nineteenth-century medicine might help shed light on the complexities of middle-class masculinity more generally. If, as Stearns, Dawson, and others have argued, the image of the "solider hero" really did come to dominate Victorian imaginings and performances of manhood, then the uncertainties of medical discourse demonstrate the difficulties in transposing such models into the civil sphere. How exactly was the model of the "solider hero" enacted outside of the army and in the comparatively placid regions of domestic life? If the experience of medicine is anything to go by, the answer might well be obliquely and inconsistently. After all, despite Myerly's claims of a "martial vision" and the undoubted prominence of war within popular entertainment and fantasy, Britain was never a truly military state, neither politically nor culturally, not even in the years after the South African War. Compared to contemporary Germany, where, as Max Weber observed, the military provided the exemplary model for social and professional organization, the British tended to keep the army at something of an imaginative distance, and it never played a direct role in domestic political life. ${ }^{116}$ In examining the ways in which Victorian medical practitioners engaged with the military paradigm, one can therefore see traces of a much wider cultural dynamic, namely, the ambivalent place of war in a liberal society.

${ }^{116}$ Max Weber, From Max Weber: Essays in Sociology, trans. and ed. H. H. Gerth and C. Wright Mills (Oxford, 1946), 257. See also Myerly, British Military Spectacle, 11-13. 